3. The Morphology and Development of the Ammonite Septum. By Henrt Hurd Swinnerton, D.Se., F.G.S., Professor of Geology \& Geography in University College, Nottingham, and Arthur EurJah Truemax, M.Se. (Read April 18th, 1917.)

\title{
[Plates II-IV.]
}

Contents.

II. Methods of Investigation

III. Materials used in the Investigation ....................... 31

IV. The Morphology of the Adult Septum ................. 31

V. Terminology of Lobes and Saddles ..................... 34

VI. The Formation of the Septum .......................... 35

VII. The Development of the Septum of Dactylioceras commune. 36

VIII. The Adult Suture of the Dactyloidæ .................... 38

IX. The Adult Suture of Dactylioceras commune ............. 40

X. Development of the Suture in Dactylioceras ............... 40

XI. Septal Sections of Dactylioceras ........................... 41

XII. Septal Sections of Tragophylloceras loscombi .............. 45

XIII. Septal Sections of Sphæroceras brongniarti ............. $\quad 47$

XIV. The General Consideration of Septal Sections $\ldots \ldots \ldots \ldots \ldots .49$

XV. Asymmetry in Suture-Lines .......................... 51

\section{Introdection.}

Sereral years ago one of us noted with particular interest the appearance of the sutures upon some badly-weathered ammonites. They were characterized by an absence of frilling and a simplicity of curvature strongly suggestive of the early stages in development. A preliminary enquiry was immediately made into the development of the sutures of Dactylioceras, and into the changes produced in the adult suture by filing the surface away in imitation of the process of weathering. This made it evident that the similarity already noted was not merely superficial, but had a widely-extended significance. It was with the view of establishing the extent and limitations of this similarity, as determined by variations in the shape of the whorl in different ammonites, that the present investigation was undertaken.

As the work advanced, the problem resolved itself into a study of the morphology and development of the septum as opposed to the suture-line. The value of the latter has long been recognized, and a distinguished succession of workers, including Sowerby, Hyatt, Neumayr, and Buckman, have made very effective use of it in solving problems of ammonite affinities. On the other hand, and apart from the suture-line, the septum itself has been comparatively neglected, and much of the information which exists concerning it must be gleaned from figures, frequently undiscussed. 
There has also been a limited discussion upon the mechanical conditions which have been concerned in modelling the septum, and upon the relations of newly-formed septa to their predecessors.

\section{Methods of Investigation.}

The chief obstacle to the study of the septum is the difficulty experienced in isolating the casts of successive chambers in such a way as to show a septal face with all its marginal frilling complete. This difficulty increases as the frilling becomes more complex. It is very seldom that a specimen breaks naturally in such a way as to show a complete septum, for the minor, if not the major, frills are almost invariably broken.

The septa shown in Pl. III, figs. $1,6, \& 7$, were cleaned with acid and tools, and supplied much useful information. The alternative method was to file away the superficial portions of a whorl in successive layers. 'This brought to view a series of sections of the septa cut approximately parallel to the periphery. Such sections are hereinafter referred to as septal sections.

To secure accuracy in working, much use was made of the instrument figured in Pl. II, fig. 1, and shown in the accompanying text-figures (1 \& 2, pp. 28-29) in plan and elevation.

This was designed with the expert assistance of Dr. P. E. Shaw, of the Physics Department of University College, Nottingham. It consisted of two parts. The one was a microscope with micrometer eyepiece and graduated rack-scale, of the kind commonly used in physical laboratories. The other consisted of a graduated turn-table (fig. 2a) mounted on another table $(b)$ which could travel horizontally. This latter had one edge provided with a vernier and laid against a fixed horizontal scale. Above the table was a double-pointed needle $(c)$ held up in the position of rest shown in Pl. II, fig. 1, by a lever $(d)$ actuated by a spring $(e)$. The needle passed loosely through the lever, and rested on it by means of a collar $(f)$. When the lever was pressed down the needle was left free to fall. As it was very light, a spring $(g)$ was inserted which, by pressure on a collar $(h)$ near the lower end, ensured a certain but gentle contact of the point with the surface of the table, or of the object of study. When the lever was released, the needle was at once lifted by it to the position of rest. The microscope was focussed upon the upper point of the needle, and its precise position, as recorded in the micrometer eyepiece and on the rack-scale, was noted. The amount of drop of the needle on to the table, or on to different points of the surface of an object, could then be easily registered-for small movements by means of the eyepiece alone; for large ones, by the rack-scale.

In obtaining the measurements for producing the contoured plan of a septum (fig. 4, p. 32) the specimen was securely fastened, with the septal face upwards, on the centre of the turn-table. This being caused to travel horizontally, a series of heights, or depths, was taken at definite intervals along one diameter of the septum. 


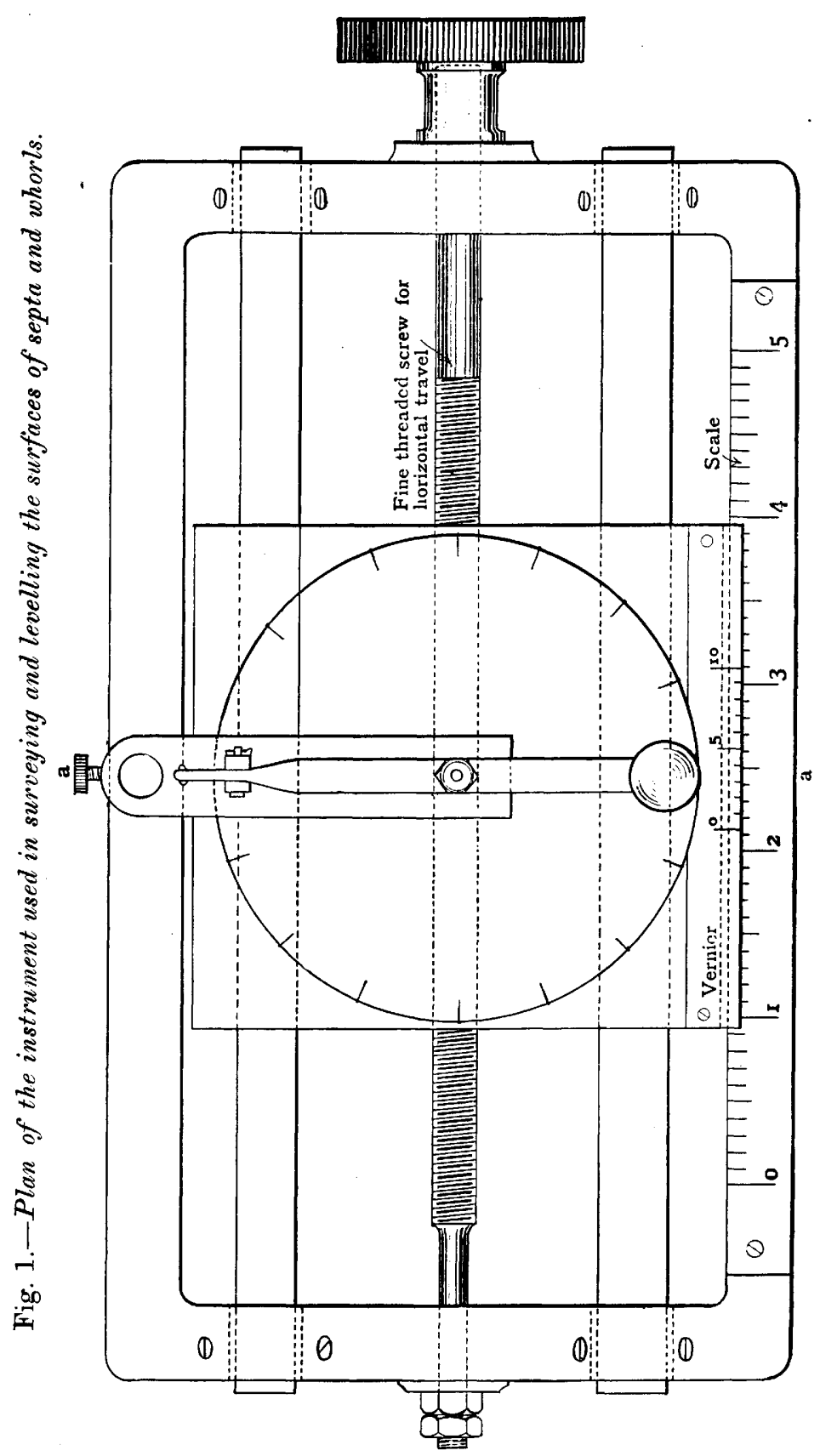


Fig. 2.- Section of the instrument used in surveying and levelling the surfaces of septa and whorls.

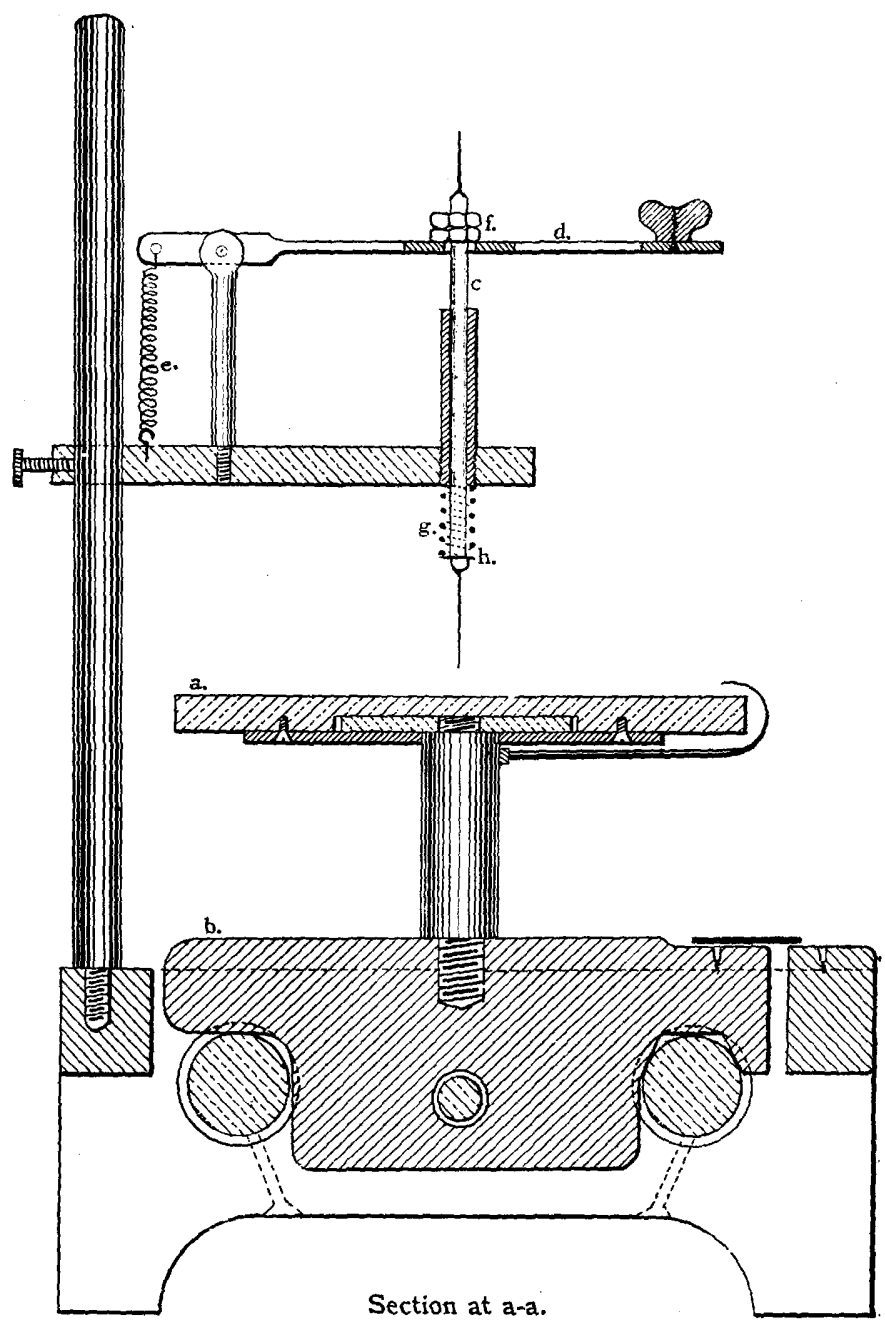


The table was then rotated through a certain number of degrees, and another diameter was brought into line with the direction of travel. This process was repeated until readings had been taken along a sufficient number of radial lines to allow of a contoured plan being made. Though this plan proved of great value, it could not be relied upon to record certain details, inasmuch as any portion of the septal surface which tended to be an 'under-cut', could not be registered by the vertically moving needle.

In the preparation of a plan (figs. $11,14, \& 17$, pp. 44, 46, \& 49) showing the precise position of successive surfaces produced by filing, the following procedure was adopted. A portion of an adult whorl, containing at least one septum, was isolatel, and the ends were ground flat and polished along a plane parallel to that of the septum. The specimen was then placed on the turn-table, with one of its ends pressed against the polished side of a metal block, fastened so that the plane of the septum lay in the direction of travel, and under the point of the needle. 'The rounded venter of the whorl was then made to pass under the needle, and readings were taken at regular intervals by means of the scale and vernier. This was repeated for the side and the dorsum. The surface of the whorl was then carefully filed away over the area occupied by the suture-line. Within the zone of complicated frilling, in a specimen of the size of Dactylioceras commune, a depth of only $\cdot 25 \mathrm{~mm}$. was removed; but in deeper and less complicated regions of the septum this was increased to $5 \mathrm{~mm}$. or even more. At each level a series of readings was taken, and the corresponding profile of the filed surface was made and introduced into the plan. With small ammonites the whole specimen was used, and a wax or plaster mould was made to hold it.

For the purposes of general systematic work, upon a large quantity of material, the methods just described involve too much labour and, incidentally, the whole of the septum may be lost by filing. Such methods were necessary in order to test the value of septal sections of one septum for the first time, and all the results recorded in the following pages were obtained by them. For most purposes, it will suffice if the worker takes a portion of a whorl containing not less than eight septa, and files it into a truncated cone or, better still, into a series of steps (Pl. II, figs. 3 \& 4). The successive septa will be cut at increasing depths, and will show most of the salient features seen in a series of sections made from one septum. As a rule, the differences between successive septa will not be great enough to vitiate the results seriously (compare Pl. II, fig. 4 with text-fig. 10, p. 43), and at the same time the series can be preserved for reference.

The camera lucida was used for drawing the sutures and septal sections of small fossils. The whorl was turned to show successive portions the drawings of which were subsequently pieced together. Sutures of larger specimens were reproduced in the manner suggested by Mr. S. S. Buckman: ${ }^{l}$ namely, by painting the chamber behind the suture and then tracing the latter.

$$
1 \text { 'Inf. Ool. Amm.' Monogr. Palæont. Soc. 1894, p. } 380 .
$$


part 1] ON THE MORPHOLOGY OF THE AMMONITE SEPTUM.

\section{Materials Used in the Investigation.}

Three species of ammonites were chosen for the main part of this enquiry, namely :-

Dactylioceras commune, because it had what may be defined as a normally shaped whorl: that is, neither depressed nor compressed to any marked degree.

Sphæroceras brongniarti, as an example of a form possessing a depressed whorl.

Tragophylloceras loscombi, as representing forms possessing elevated and compressed whorls.

In the two former the development of the suture was worked out in the same specimens as those from which the septa used for making septal sections were taken. In the first, a series of septa was also cleaned, while the protoconch and first whorl were reconstructed in wax, and arranged in such a way that the separate chambers could be taken apart and the septa examined.

Fig. 3.-Graph showing the average profile of the adult septum of Dactylioceras commune (see Pl. III, fig. 1).

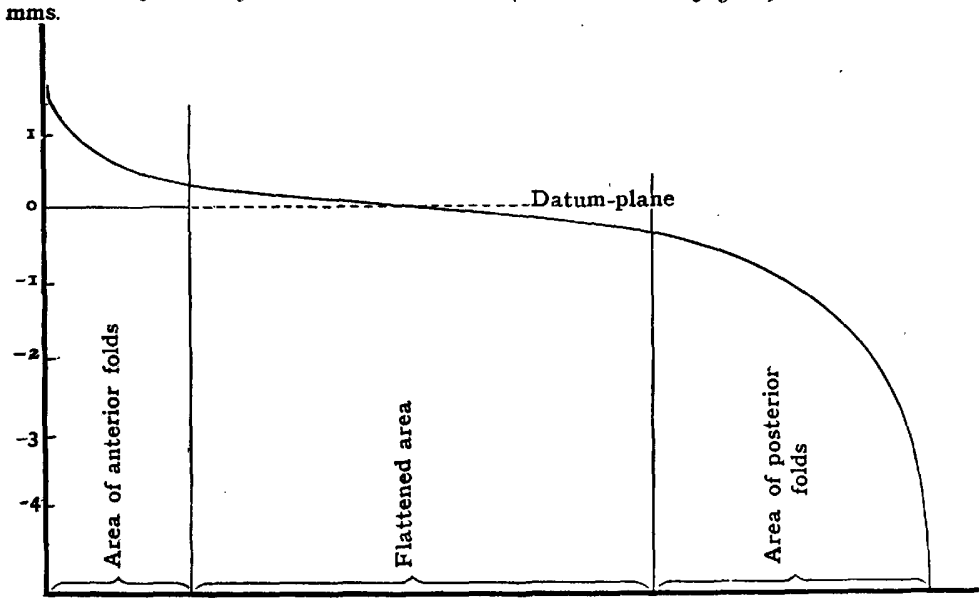

Area in front of successive contours.

We are indebted to Mr. W. D. Lang, F.G.S., of the British Museum (Natural History), for samples of the third, and we relied for the sutural development upon the figures of Mr. L. Spath, 1 which we reproduce here in fig. 12 (p. 46). The details of other material will be given below.

\section{The Morphology of the Adult Septum.}

The consideration of the morphology of the septum niay be approached from a study of the contoured plan (fig. 4), which was made from a cleaned septum of an adult Dactylioceras commune.

1 ' On the Development of Tragophylloceras loscombi' Q. J. G. S. vol. lxx (1914) p. 341. 
The septum was $14 \mathrm{~mm}$. broad, and measured $9.25 \mathrm{~mm}$. from dorsum to venter. The datum-plane taken passed through the centre of the ammonite at right angles to the plane of coiling, and touched the septum tangentially in its median line.

The general form assumed by septa has been aptly described by S. P. Woodward ${ }^{1}$ as

' nearly flat in the middle and folded round the edge like a shirt-frill, where they abut against the outer shell-wall.'

The anterior folds are referred to as saddles and the posterior

Fig. 4.-Contoured plan of the adult septum of Dactylioceras commune (see Pl. III. fig. 1).

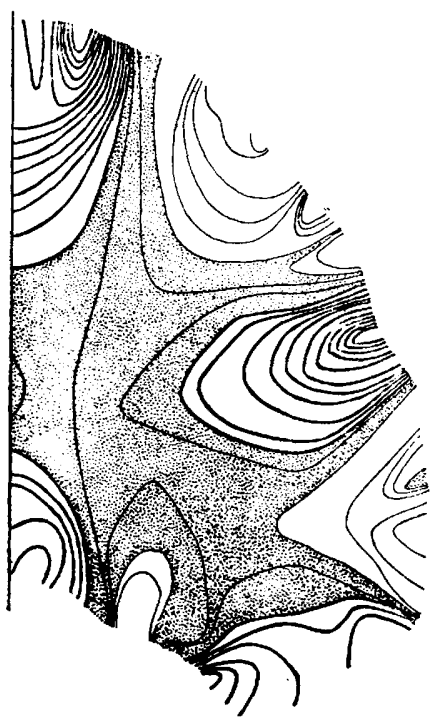

[The shaded portion is the flattened area; the thick lines represent the posterior folds, or lobes: the thin lines represent the anterior folds, or saddles. The contours are drawn at intervals of $0.25 \mathrm{~mm}$.] although it should be noted that sections across the septum in as lobes. The extreme anteroposterior range from crest of saddle to trough of lobe was $6.5 \mathrm{~mm}$.

The graph shown in fig. 3 (p.31) was made by finding the relative areas of septum in front of successive contour-lines. It shows that nearly 52 per cent. of the area of the septum lies between contours only $0.75 \mathrm{~mm}$. apart. 'This portion of the septum, with its extensions into the folded region, is shown with dotted shading in fig. 4. This flattened area is concentrated chiefly in the centre of the septum, and coincides approxjmately with the datum-plane. 'The central area is crossed by very slight undulations, which unite the corresponding folds of the opposite sides, or of the venter and dorsum, in all three genera. In highly compressed or depressed ammonites these undulations become more or less strongly developed folds.

From the graph it is also apparent that the area occupied by the posterior folds is much greater than that occupied by the anterior folds, and further that the former are more acute than the latter. It thus appears that the septum as a whole is convex for- 
different directions are here convex there concave. Brancol and Hyatt ${ }^{2}$ both observe that in median sections of ammonites the profile of the septum, passing as it does along the troughs of the dorsal and ventral lobes, necessarily appears convex forward. On the other hand, it may be remarked that profile sections along the crests of individual saddles are coneave forwards. Thus the form of an anterior fold of the septum is comparable with that of a horse's saddle, or with the heterocolous articular surface of a bird's cervical vertebra, since sections along the crest, and at right angles to it, are concave, and convex respectively.

NoтE.-J. F. Blake suggested that the forward convexity of the septum is evidence of pressure from behind the animal, and that the saddles represent parts of the edge which have yielded to the pressure. In more recent work Pfaff ${ }^{3}$ also concludes that the form of the septum has been determined largely by pressure upon the posterior part of the animal. Probably, as in the Pearly Nautilus (Willey ${ }^{4}$ ), the chambers of the shell were filled with gas secreted by the veins of the mantle. In ammonites the vigour of secretion may have been so great that the gas exerted sufficient pressure upon the soft mantle to make it bulge forward, while the septum was being deposited. The formation of a new septum must always have been preceded by a period of rapid evolution of gas. Perhaps the pressure thus produced helped the forward shifting of the posterior end of the long worm-like body of the ammonite.

In all three types of ammonites considered, the axes of the folds are always approximately at right angles to the whorl-surface (Pl. III), and they maintain this relation throughout all the changes in shape of the whorl which take place during development or during the distortions associated with asymmetry (Pl. IV, figs. 1, $4, \& 9)$.

Each pair of folds behaves independently of the others. Thus, in the development of the septum of Dactylioceras commune the axis of the internal saddle is at one stage almost continuous with that of the external saddle (PI. III, fig. 3) ; but as, during development, the whorl increases in height, it comes into a similar relation with the first lateral saddle (P1. III, figs. 1 \& 2). The same independence is manifested also in the development of the septum in Tragophylloceras. ${ }^{5}$

This independence finds further expression in the variations of arrangement of the folds according to the shape of the whorl. When this is round, as, for example, in Lytoceras, they radiate from a central point; when it is impressed dorsally, as, for instance, in Dactylioceras and Spharoceras (Pl. III, figs. $1 \& 7$ ), the internal folds come into relation with the corresponding external saddles, and the number of dorsal and ventral elements is nearly equal; when it is compressed, as in Tragophylloceras (Pl. III,

1 'Beiträge zur Entwickelungsgeschichte der Fossilen Cephalopoden' Palæontographica, pt. 2, vol. xxvi (1879-81) p. 50 .

2 'Genesis of the Arietidæ' Smithson. Contrib. to Knowledge, No. 673, 1889.

3 'Form \& Bau der Ammonitensepten \& ihre Beziehungen zur Suturlinie' Jahresb. des Niedersächs. Geol. Verein, vol. iv (1911) p. 208.

+ 'Contribution to the Natural History of the Pearly Nautilus' Zool. Results... . New Britain, New Guinea, \&c., pt. vi, 1902, 4to. Cambridge.

5 L. F. Spath, Q. J. G. S. vol. Ixx (1914) pl. xlix.

Q.J. G. S. No. 289. 
fig. (6), the ventrally situated folds of the external series come into line with their fellows of the opposite sides, and consequently the elements of the venter exceed those of the dorsum by the number of folds which thus cross the central area. ${ }^{1}$

\section{Terminologr of Lomes axd SAddies.}

Some of the existing terminologies for lobes and saddles of the suture-line cannot be adopted for the present purpose, because they are to a great extent arbitrary. 'Thus the term superior, is applied to the first two lateral saddles, although it tits in with the accepted conventional method-used even in our own figuresof representing the septum, is quite wrong when the septum is correctly placed with its venter downwards, in the attitude which it is believed to have assumed when the animal was alive.

The terminology suggested by Mr. S. S. Buckman 2 is most nearly in accordance with the facts of development, and will be adopted here. He gives the name of external saddles to the pair on each side of the ventral lobe; and uses the term lateral for the others. The difference thus implied is a real one: the external saddles originate from the large median saddle ('aussensattel' of Branco) of the first septum by the appearance upon its crest of a median lobe (Spath, op. cit. 1914, p. 341; A. E. True$\left.\operatorname{man}^{3}\right)$. The lateral saddles, on the contrary, appear as simple folds on the umbilical angle, and travel thence towards the venter (Pl. III ; and Spath, op. cit. pl. xlix, figs. $2 a \& 2 b$ ).

The development of the folds on the dorsum apparently follows the same lines as those just laid down for the venter. 'Thus, the first septum shows occasionally a median saddle (fig. 12.a, p: 46; Spath, op. cit. pl. xlviii, fig. $2 c$ ). In the second septum this has given place to a median dorsal lobe flanked by the internal saddles. The remaining elements appear at the umbilical angle, and travel towards the niedian dorsal line (see figs. $9 c, d, \& e$, p. $42 ; 12 c \&$ e, p. 46 ; and $15 c, d, f, \& g$, p. 48$)$.

Although the distinction into laterals and auxiliaries may be convenient for descriptive purposes, it does not correspond to any morphological difference between the folds-inasmuch as the auxiliaries also appear for the first time as simple folds on the umbilical wing of the septum, and travel towards the venter or towards the dorsum, as the case may be. Moreover, the auxiliaries of one ammonite may correspond to the laterals of another. Thus, development shows that the large second lateral of Trayophylloceras loscombi is the strict homologue of the small tirst. auxiliary of Dactylioceras.

1 The septal aponeurosis of ammonites does not seem to have been so well developed as in Nautilis. In them the fibres were apparently isolated and attached to the shell along a wavy line at points indicated on the suture-line by denticles. Pressure upon a membrane thus attached by its margin must produce folds at right angles to the periphery.

2 'Yorkshire 'Type Ammonites' vol. i (1909-12) p. ix.

3 'The Lineage of Tragophylloceras loscombi' The Naturalist, 1916, p. 222. 
part 1] ON THE MORPHOLOGY OF THE AMMONITE SEPTUM.

\section{The Formation of the Septum.}

Evidence bearing upon the mode of deposition of the septum is scanty. In an adult specimen of Dactylioceras commune from Grantham, the last septum was found to be only in part secreted. Its suture was clearly visible as a white line at the umbilical angles. Here the secretion of the septum was evidently well-advanced, but elsewhere it could be seen only as a faint dark line-possibly due to a-conchiolin membrane. Septal sections seemed to indicate that the septum was incomplete internally; but a definite statement cannot be made, for it had evidently been disrupted when the shell was becoming filled with mud. The evidence shows that the

Fig. 5.-Last two suture-lines of two ammonites showing the last suture incompletely formed.

b
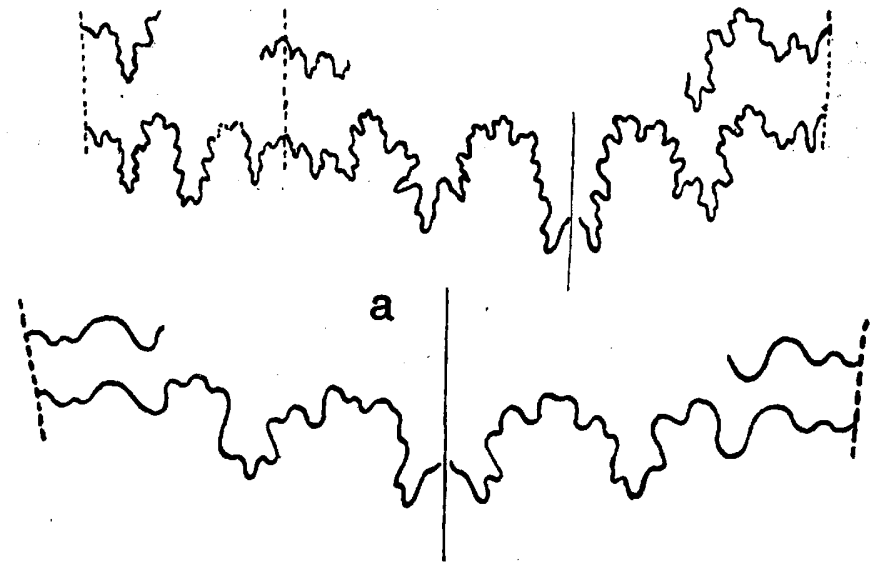

$a=$ Dactylioceras commune, Grantham. Diameter $=57 \mathrm{~mm}$. $\mathrm{b}=$ Polymorphites jupiter, Old Dalby. Diameter $=18 \mathrm{~mm}$.

secretion commenced in the region farthest removed from the siphuncle. Partly formed septa, showing the same peculiarities, have also been noticed in Polymorphites jupiter d'Orbigny (fig. $5 b$ ).

The formation of the septum in ammonites seems to have taken place in the same manner as in living Nautilus. It has long been known ${ }^{l}$ that in the latter the deposition of calcareous matter begins at the sides of the shell, and proceeds towards the siphuncle. Willey (1902) observed further that the secretion of a septum was preceded by the formation of a conchiolin membrane, upon which the calcareous matter was deposited.

The septa, just described for Dactylioceras and Polymorphites,

1 F. A. Bather, 'Growth of Cephalopod Shells' Geol. Mag. dec. 3, vol. iv 1887) p. 4.47. 
were complete in all sutural details and, though only formed in part, were situated at the normal distance from the preceding septa. These facts run counter to the views of Riefstahl 1 supported by Buckman 2 ; and, along with the observations of Willey (1902) upon Natilus, they furnish further support, if such be needed, for those of Bather ${ }^{3}$ and Appellöf.4 According to Riefstahl, the last septum was formed in contact with the previous one, and became separated by the growth of the intervening shell-wall. He based his view upon the microscopical study of the sepion. This, however, is so highly modified that it would not be safe to use it for throwing light upon the formation of the septum of the (comparatively) closely-allied belemnite, still less upon that of the only very distantly-related ammonite.

\section{The Development of the Septum of \\ DACTYLIOCERAS COMML XE.}

\section{(1) The Second Septum.}

A wax model enlargement was made of the second septum, and from this a contoured plan (fig. 6) and a graph (fig. 7), like those

Fig. 6.-Contoured plan of the second septum of Dactylioceras commune shown in Pl. III, fig. 4.

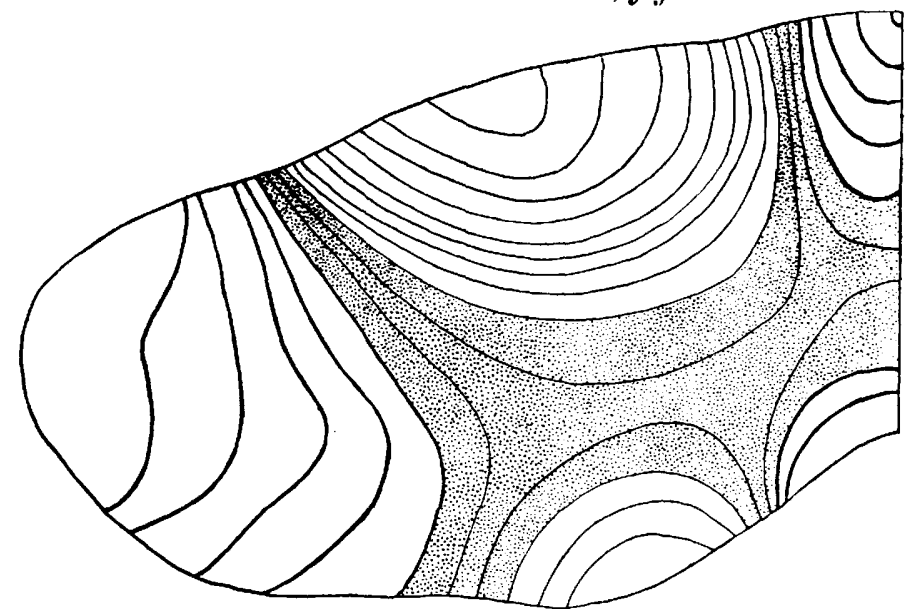

[Explanation as in fig. 4 (p. 32). The contours are drawn at intervals of $0.01 \mathrm{~mm}$.]

already described for the adult septum, were constructed. The

1 'Die Sepienschale \& ihre Beziehung zu den Belemniten' Palæontographica, vol. xxxii (1886) p. 20.

2 'Notes on Nautili \& Belemnites' Proc. Geol. Soc. vol. xlvii (1891) p. 165.

3 'Shell-Growth in Cephalopoda' Ann. Mag. Nat. Hist. ser. 6, vol, i (1888) p. 298.

4 'Die Schalen von Sepia. Spirula, \& Nautilus' Kongl. Srenska VetenskapsAkad. Handl. vol. xxv, No. 7 (1893) p. 28. 
septum itself was $0.95 \mathrm{~mm}$. broad, and $0.22 \mathrm{~mm}$. from dorsum to venter. The extreme antero-posterior range from the crest of the saddles to the trough of the lobes was $0.16 \mathrm{~mm}$. The area shaded in the plan is comparable with the flattened area of the adult, but is relatively much less extensive. It lies between contours $0.03 \mathrm{~mm}$. apart, and occupies 30 per cent. of the area of the septum. On the whole, the septum tends to be concave rather than convex forwards.

It is evident that the septum-secreting portion of the mantle, which was strongly convex at the time of formation of the protoconch and even of the first septum, had already begun to feel the influence of that pressure, which in later life became strong enough to impose upon it a marked concavity. In the more primitive ammonoids, especially the Asellati, ${ }^{1}$ the form of the earlier septa proves that this influence did not develop quite so rapidly in them as it did in the specialized forms represented by Dactylioceras.

(2) Comparison of the Second with the Adult Septum.

On comparing the second septum of Dactylioceras (Pl. III) with the adult septum, it is seen that, a part from the peripheral zone, the latter shows all the essential features of the former, so that, except for the increase in-size and flattening of the elements, the major portion of the septum has undergone no significant change during development. The

Fig. 7.-Graph illustrating the average profile of the second septum of Dactylioceras shown in Pl. III, fig. 4.

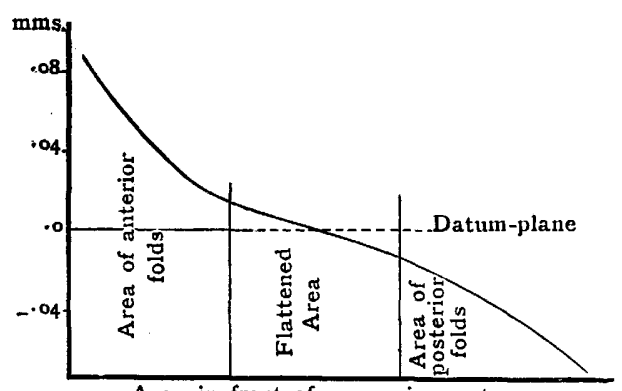

Area in front of successive contours. changes already mentioned above : namely, the relative movements of the first lateral saddle as the height of the whorl increases, and the origin of the new lobes and saddles on the umbilical wing of the septum, are confined to the marginal area.

It must not be supposed, however, that this general agreement of the major portion of the adult septum with the whole of the second septum is due merely to a simple enlargement of the area which secreted the latter. Had this been the case, the siphuncle would have retained the subcentral position of the second septum throughout life. During the growth of the first and second whorls, however, it gradually shifts to the ventral margin, and thus comes to lie within the frilled peripheral zone. In some cases, according

I W. Branco, Paløontographica, vol. xxvii (1880) p. 68 . 
to Branco, ${ }^{1}$ the siphon lies near the internal margin of the early septum, as in most latisellate ammonoids; while in certain forms, as, for example, Goniatites lamed var. calculiformis, it occupies a ventral position from the first. Despite these variations in position of the siphuncle, the development of the septum pursues a detinite course. Assuming that there is no actual migration of the siphuncular corl through the substance of the mantle, it may be taken as furnishing a datum-point. It then seems as though a portion of the mantle ventral to this point is withdrawn from taking part in the secretion of the septum, and that the mantle dorsal to it increases, especially on the umbilical wings. Throughout development, and also despite all the distortions associated with asymmetry (Pl. IV), the siphuncular cord and ventral lobe remain intimately related.

The close similarity in form between the early septum and the central part of the adult septum suggests that the study of the latter may give some clue to the development. In actual practice the contouring of a cleaned septum was found to be unsatisfactory for this purpose, inasmuch as the instrument could not be made to deal efficiently with undercut or even vertical portions of the surface. On the other hand, septal sections proved highly satisfactory. Before considering these, it will be necessary to provide a basis for comparison by giving an account of the sutureline of Dactylioceras and of its development.

\section{The Adult Suture of the Dactroidx. .}

Before proceeding to the detailed description of the adult suture in the specimen from which both developmental details and septal sections were obtained, it will be helpful to refer briefly to the general features of the suture-lines in the family Dactyloidæ and in the Getoceran forms from which it has been derived. Unfortünatelr; the material at our disposal was neither abundant enough nor suffieiently complete to permit the elucidation of major and minor lines of descent within these families. Nevertheless, there was sufficient to lead to the detection of certain tendencies which throw much light upon the problem now being considered.

The material examined included the following species :-

Dactylioceras commune (Sowerby). I Peronoceras fibulatum (J. de C. Sowerby).

D. crassum (Young \& Bird).

D. annulatum (Sowerby).

D. turriculatum (Simpson). Porpoceras andræi (Simpson). Coloceras pettos (Quenstodt). C. fonticulus (Simpson).

The general relationships of some of the variations of the suture-lines within this family may be illustrated from one specimen of Dactylioceras by a comparison of its last suture with that of a slightly earlier one, namely, the tenth from the last (fig. 8 , ii \& iii).

During the interval between the deposition of these two septa

${ }^{1}$ op. cit. p. 62. 
part 1] ON THE MORPHOLOGY OF THE AMMONITE SEPTUM.

some change-which, following the prevailing custom, may be ascribed to the onset of senile decay-had taken place in the animal. This expressed itself in the suture-line by a considerable decrease in the antero-posterior range of the lobes and saddles, accompanied by a swinging forward of the umbilical portion of the

Fig. 8.-Suture-line of Dactylioceras
and Coeloceras.

$\begin{array}{cc}\text { Fig. 8.- Suture-line of Dactylioceras } & \text { changes, which lead } \\ \text { and Coeloceras. } & \text { to a crumbling-down }\end{array}$

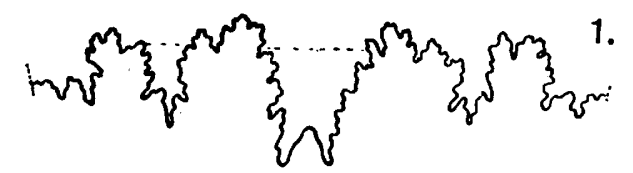

suture-line. These to a crumbling-down of the apices of the saddles to approximately the same plane, strongly suggest a diminution in the forward convexity of

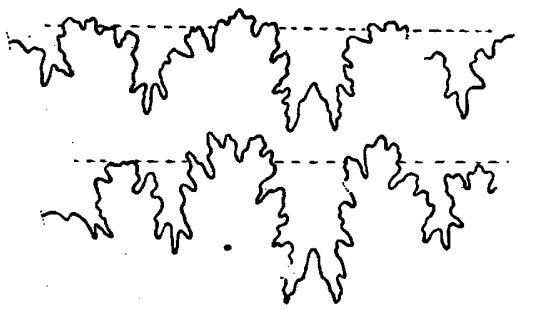
the septum. Mean. while the saddles broadened out, and the demarcation from the lobes became more

3. ill-defined. In minor details the later septum seemsat first more intricately wrinkled, a feature which is still better exhibited in

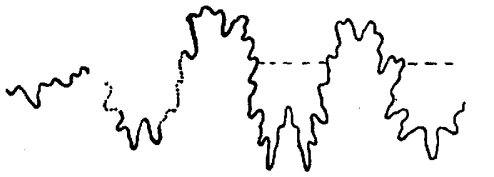

4. other specimens (fig. $8, i)$, some of which show these and other ' ageing' characters through a wide range

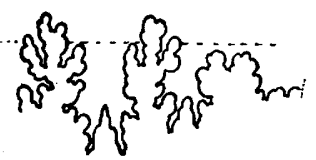

5 . of septa. This complexity is strongly suggestive of the wrinkling of a collaps-

[1-3=Dactylioceras commune; 2 , at the diameter of $45 \mathrm{~mm} . ; 3$, at the diameter of $39 \mathrm{~mm} .10$ sutures earlier in the same specimen. $4=$ Coloceras fonticulus from Whitby ; diameter, $28 \mathrm{~mm} .5=$ Coloceras pettos from Baden; diameter, $27 \mathrm{~mm}$.] ing or flaccid bladder, as opposed to the simpler and more turgid outlines of the folioles in earlier septa, and suggests a diminution in the vigour of gas-secretion in the declining period of life.

The features that distinguish the earlier septum become more obvious in the primitive members of the family, and lead by an almost perfect gradation of changes to the condition observed in Coloceras pettos (fig. 8, v).

The Dactyliocerates are evidently a decadent offshoot of Coeloceras. ${ }^{1}$ In them are to be seen the phenomena which

1 S. S. Buckman, 'On the Grouping of some Divisions of so-called "Jurassic" Time' Q. J. G. S. vol. liv (1898) p. 442. 
characterize the first stages in the simplification of the suture-line, a simplification that is carried to such extremes in Cretaceous ammonites.

\section{The Adrlt Sttere of Dactylloceras Commene.}

'The adult suture (fig. $9 i$, fig. $10 \mathrm{~m}$ ) shows externally a deep ventral lobe divided by a median saddle, and flanked by broad external saddles. The first lateral lobes are almost as wide, but not so deep, as the ventral lobes; while the first lateral saddles are of smaller proportions than the external saddles, presenting in this respect a marked contrast with Tragophylloceras. The second lateral lobes are very small, and the two auxiliary saddles of the external series are insignificant. Internally, the dorsal lobe with its minute median saddle is the most important feature, being exceeded in depth only by the corresponding lobe of the external series. A pair of internal saddles, about as high but slightly narrower than the first lateral saddles, and a pair of smaller auxiliaries separated from the internal saddles by internal lobes, are also present. All the features of the suture-line, except the auxiliaries, are complicated by the presence of frillings or denticulations. On each of the external saddles are three main divisions similar to the simple divisions on the internal saddles. The first lateral lobe of the left ${ }^{\text {l }}$ is markedly trifid. 'That of the right side is abnormal. A similar' asymmetry has been noticed in other ammonites, as, for example, in Sonninia. ${ }^{2}$ While these major frillings are symmetrically developed on each side of the median line, the minor frillings are less constant, and frequently give rise to asymmetry. Thus, although the three minor frillings on the central division of the external saddle are present on each side, the small frills on the dorsal foliole of the same saddle are much more developed on the left than on the right side. It appears, therefore, that, at least in such retrogressive types as Dactylioceras, only the major frillings can be of systematic importance. The minor frillings, which further complicate the suture, show even on opposite sides of the same suture an ineonstancy that may be associated with the phenomena of decline discussed above.

\section{Developmest of the Sutere is D.hCtralocer.ts.}

The first suture (fig. $9 a$, p. 42) of Dactylioceras shows the usual angustisellate condition.

In the second suture $(9 b)$ a well-rlefined ventral lobe is present. which is as broad as it is deep. The dorsal lobe is similar, but smaller; buth are deeper than the lateral lobes. As in the adult suture, the external saddles are the largest, and the internal saddles come next in size. The first lateral saddle is just appearing as a low fold close to the umbilical angle.

1 Rjght and left as used in the deseription refer only to the figures.

2 S. S. Buckman, 'Inf. Ool. Anmonites' Monogr. Pulæont. Suc. 1894, p. 381. 
part 1] ON THE MORPHOLOGY OF THE AMMONITE SEPTUM.

In the seventh suture $(9 c)$ the same proportions are maintained. The new features to be noticed are the appearance of a median ventral saddle, the increase in size of the lateral saddle, and the presence of another saddle, the internal auxiliary, near the umbilical angle.

The folds just described persist throughout the remainder of the first three whorls, with little change in their relative proportions. Mean while crimping begins, and the first external auxiliary appears near the umbilical angle $(9 e)$.' The external saddle becomes trilobed, and thus resembles the internal saddle of the adult. The first lateral lobe on the left is trifid, while that of the right is only bifid ; thus, even at this early stage, the curious asymmetry already noted in the adult has become established.

In the fourth whorl $(9 f)$ frilling becomes still more marked.

In the fifth whorl $(9 g)$ crimping is carried farther, but its small taxonomic value is made evident by a comparison of the right and left sides. The left lateral lobe is wide, and has the primitive five-fingered appearance of the corresponding lobe in Coeloceras (fig. 8, iv \& v, p. 39). Up to this stage the outlines are all manifestly turgid.

In the sixth whorl (fig. $9 h, \mathrm{p} .42$ ) conditions giving rise to flaccid outlines have begun to set in.

The development of the dorsal series of lobes and saddles proceeds along similar lines to that of the ventral series, but the details are later in appearing. For example, no signs of frilling are present on the lobes and saddles of the dorsum at the fourth whorl $(9 f)$, yet marked frilling was already manifest in the ventral series before the end of the third whorl $(9 e)$. Again, the median saddle of the dorsum does not appear until the fifth whorl, and it always remains small; but the corresponding saddle of the ventral series is present three whorls earlier. Further illustrations of the same principle are afforded by the development of Tragophylloceras and Spharoceras. Branco noted a similar feature in many other ammonites. The conditions in Clymenia (Palæontographica, pt. 2, vol. xxvii, 1880 , pl. viii) are exceptional, for the dorsal folds are more deeply divided than the ventral. The fact that in it the siphuncle is dorsal suggests that the complexity of folding is, in some way, associated with the position of the siphuncle.

\section{Septal Sections of Dactylioceras.}

In the foregoing pages it has been shown that the central area of an adult septum is strikingly similar to the earlier septa. This fact suggests that, if septal sections were made, they would show some resemblance to the suture-lines at different stages in development.

Fig. 10 (p. 43) shows a series of such sections made at the zonal lines shown in fig. 11. Thus section $b$ represents the ground edge of the septum at zonal line 2 of fig. 11 (p. 44). This illustrates the extraordinary Hatness of the innermost area of the septum. 
Fig. 9.-Derelopment of the suture-line of Dactylioceras commune (figured in Pl. II, fig. 2).

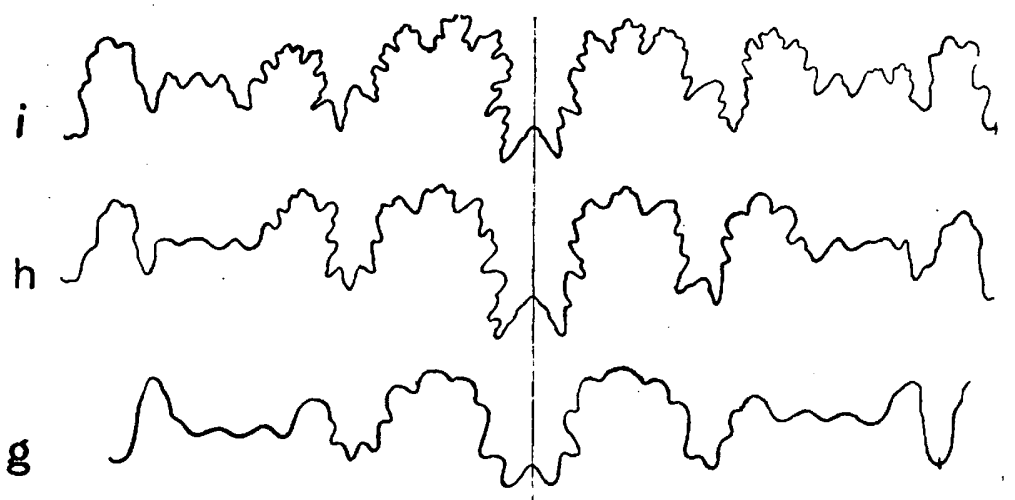

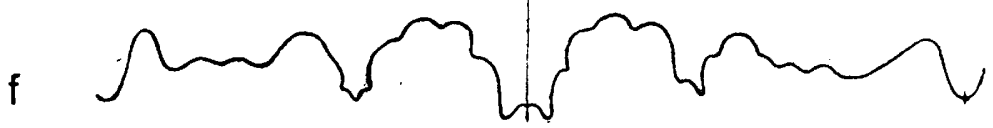

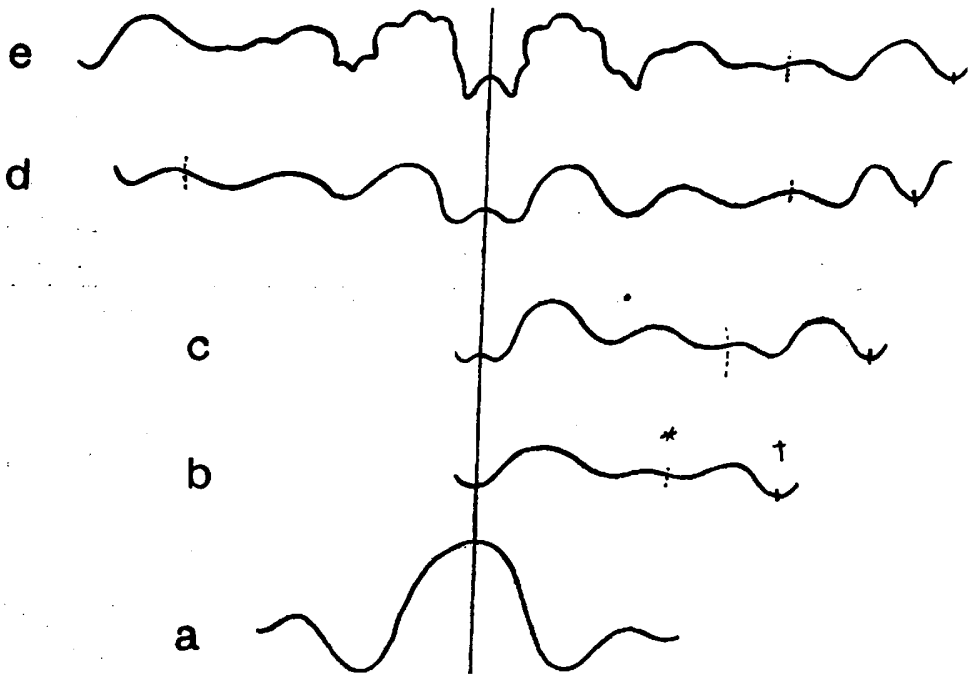

$a=$ First suture $\times 28 . \quad d=$ Suture at $1 \frac{3}{4}$ whorls $\times 28 . \quad g=$ Suture at $4 \frac{3}{4}$ whorls $\times 8$. $b=$ Second suture $\times 28 . \quad e=$ Suture at $2 \frac{3}{4}$ whorls $\times 15 . \quad h=$ Suture at $5 \frac{8}{4}$ whorls $\times 4$. $c=$ Seventh suture $\times 28 \quad f=$ Suture at $3 \frac{3}{4}$ whorls $\times 12 . \quad i=$ Suture at $6 \frac{3}{4}$ whorls $\times 2$, 
Fig. 10.- Series of septal sections made from one of the latest. septa of the Dactylioceras figured in Pl. II, fig. 2. $\times 2$.

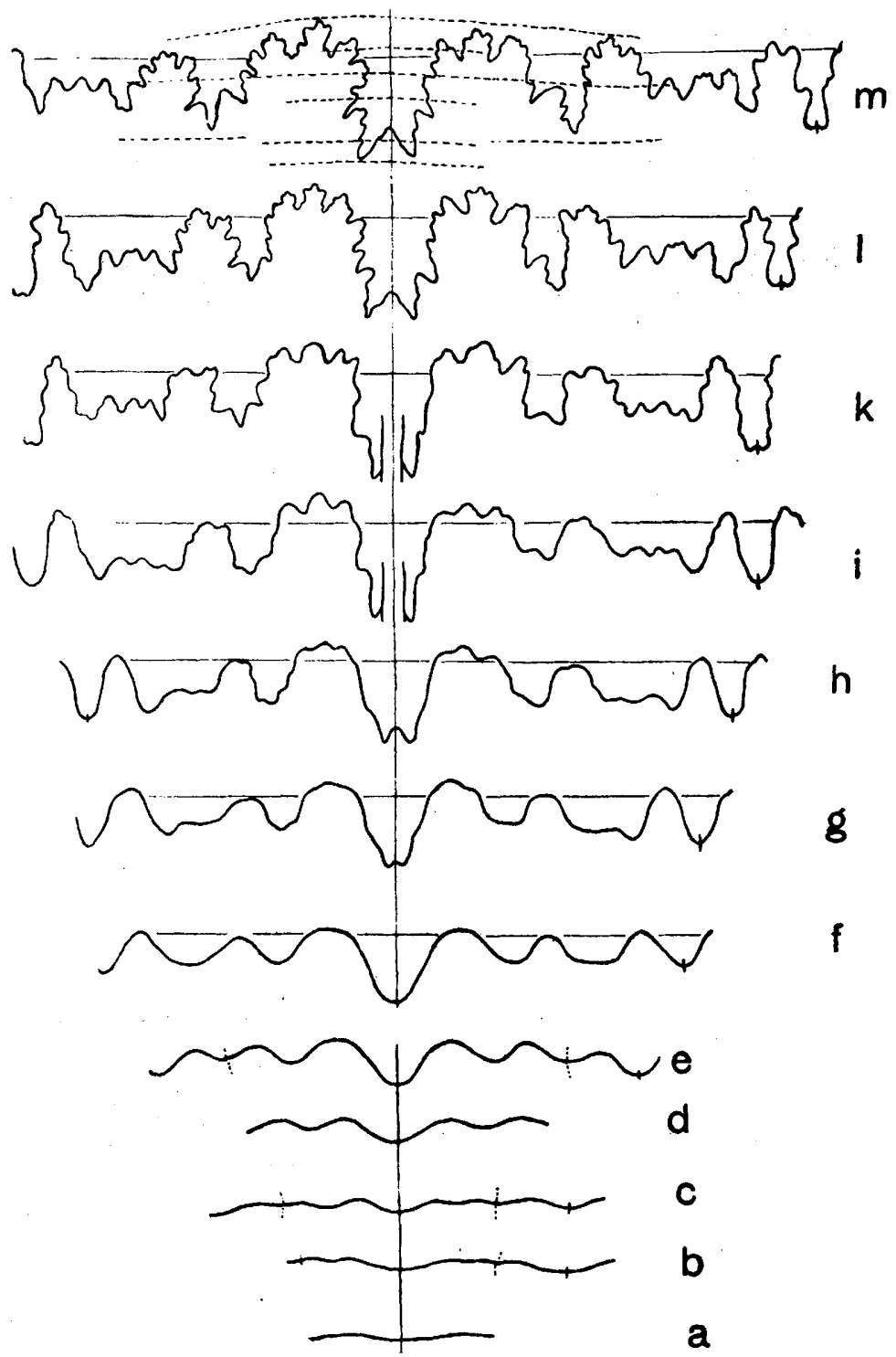

[The horizontal lines indicate the position of the datum-plane. The broken lines indicate the positions of the ribs on the original surface. The letters correspond with the numbers of fig. 11, p. 44.] 
Passing outwards from this, the sections show ever more clearly defined indications of folding until at section $e$ (fig. 10, p. 43) they are distinct enough to permit of comparison with the second suture $(9 b$, p. 42). Such comparison shows that, except for the flattening of the features, all essential characters of the latter are to be seen. If it were not for the enlargement of the first lateral saddle, the fifth septal section (fig. $10 e$ ) would be identical with the second suture (fig. $9 b$ ). This discrepancy is slightly rectified in the sixth section (tig. $10 f$ ).

Fig. 11.-Section of whorl $(\times 6)$ along the datum-plane of the septum whereof sections are shown in fig. 10, p. 43 .

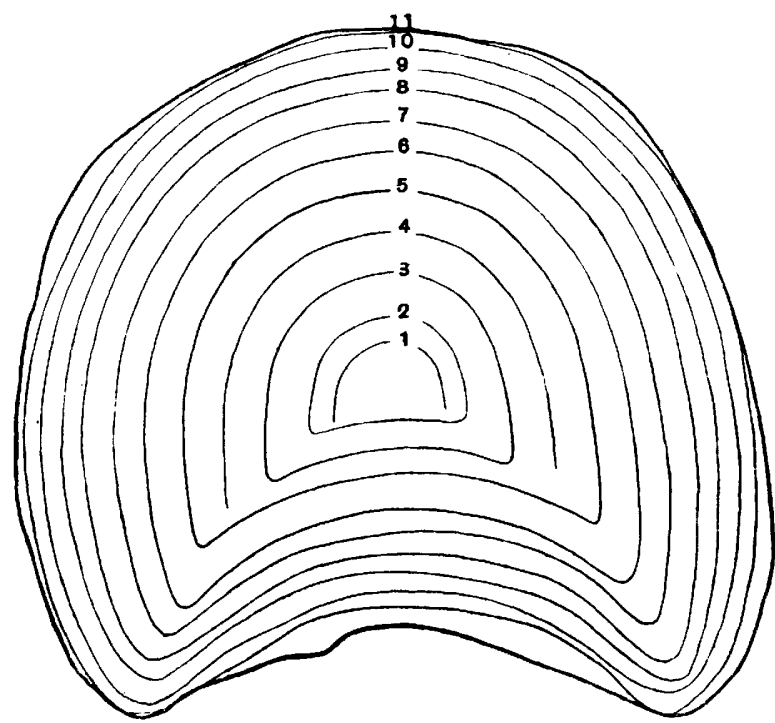

[The lines parallel to the periphery show the positions of these sections. The numbers $1,2,3$, etc. correspond to the letters $a, b, c$, etc. in fig. 10.]

The seventh section $(10 g)$ is comparable with the seventh suture $(9 c)$ and those which follow it as far as the second whorl $(9 d)$, or even a little later. This is shown by the appearance of the internal auxiliary, and of faint indications of frilling on the external saddles and on the first lateral lobes. It should be noticed that at this stage, so far as main folds are concerned, the tendency to flattening has been reversed, and the features are now relatively deeper and narrower than in development. Section 8 (fig. $10 h$ ) is comparable with the sutures in the third whorl $(9 \rho)$, differences being similar to those noticed in the previous section: that is to say, the crimping, having just made its appearance, is (on the whole) flatter than in the corresponding developmental stage. 
part 1] ON THE MORPHOLOGY OF THE AMMONITE SEPTCM.

It is interesting to notice that the asymmetry due to the abnormal characters of the first lateral lobe of the right side is shown clearly in the septal sections as well as in the development of the sutures, a fact which emphasizes the soundness of the conelusion $_{1}$ to which this comparison seems to be leading, that the septal sections may be used for ascertaining some of the leading points in the development of the sutures.

Septal section 9 (fig. $10 i$ ) is comparable with the sutures of the fourth whorl (fig. $9 f^{\prime}$ ) except that the second auxiliary has made its appearance, and that the frilling has changed in the same way as did the major folds of the earlier sections : that is to say, they have become deeper and narrower than in the corresponding sutures. Their relative proportions are the same : for example, in the sutures of the fourth whorl $\left(9 f^{\circ}\right)$ the external saddles are asymmetrically subdivided. A similar asymmetry may be detected in the ninth section $(10 i)$. The tenth section $(10 \%)$ also bears much detailed similarity to the sutures of the fifth whorl $(9 g)$ : observe, for example, the five-fingered appearance of the left lateral lobe. By this stage in development the animal has begun to assume adult characters.

\section{Septal Sections of Tragoly ylloceras loscombi (J. Sowerby).}

The shape of the whorl of Dactylioceras does not depart greatly from that which is normal for ammonites. We have yet to examine to how great an extent the characteristic just observed in Dactylioceras is true for ammonites in which the whorl has become either compressed or depressed. As an example of a type with a compressed whorl, Tragophylloceras loscombi is here taken. The septal sections shown in fig. 13 (p. 46) are lettered for comparison with the stages in the sutural development (fig. 12). The positions of the sections in the whorl are indicated in fig. 14 .

The specimen of this genus used by us was a young one. Its size and last suture show that it comes in between $k$ and 7 of Mr. Spath's series (op. cit. 1914, p. 340 ; see fig. 12). It shows differences from his specimens, which must be borne in mind when comparing septal sections made from it with the developmental series given by him. For example, the great size of the terminal leaflets of the external and first lateral saddles shown in his sutures at $k$ and $l$ does not appear in the last suture of our specimen. This fact may account for the relative smallness of those leaflets in the septal sections. Again, Spath's figures of sutures $h$ and $i$ do not form a continuous series with $g$ and $k$ : compare, for example, the second lateral saddle and also the terminal leaflets of the external saddles. We have been unable to detect this break in the earlier sutures of our specimen, so that its absence in the septal sections can hardly be accepted as evidence against their value. 
Figs. 12-14.- Tragophylloceras loscombi (J. Sowerby) firom Lyme Regis.

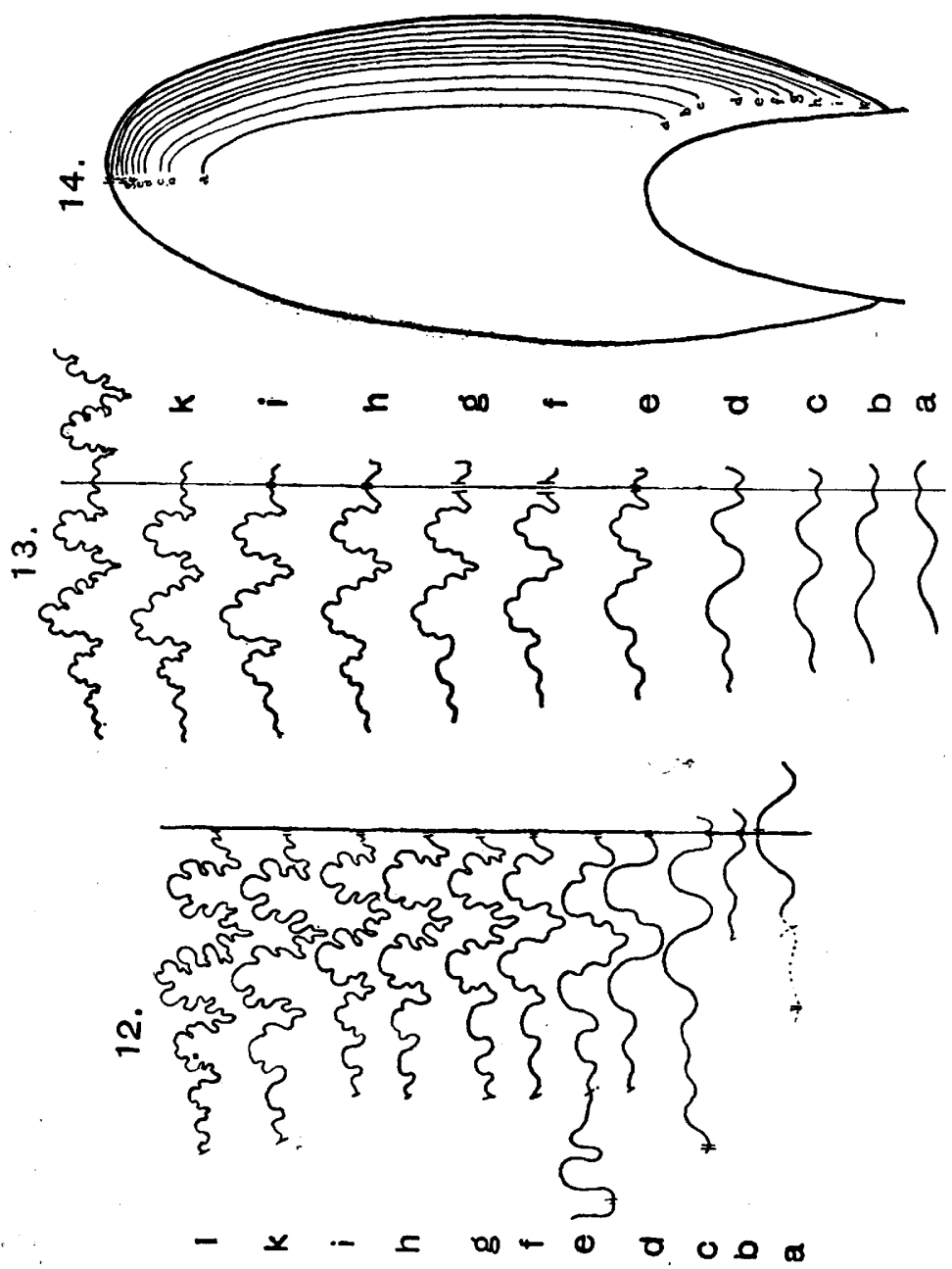

[12 = Development of suture (from L. F. Spath, op. cit. p. 341); 13=Series of septal sections made from one septum, $\times 2 ; 14=$ Section of the whorl along the datum-plane of that septum, showing the positions of these septal sections.? 
As in Dactylioceras, the smaller details of the suture are so asymmetrical about the median line as to indicate that they are of little consequence in taxonomic discussion. Here, again, the comparison of the developmental series and the septal sections may be confined to the more outstanding features. The sections give nothing comparable with the first suture, but the imnermost sections (fig. $13 b \& c$ ) are almost identical with the seventh suture (fig. $12 c$ ). This similarity is emphasized by the presence of the ventral saddle which, by acceleration in development, appears earlier in development in Traqophylloceras than in Dactylioceras: a difference in the time of appearance which is manifested also by the sections of the two types. As in Dactylioerras, the fresh lobes and saddles appear at the umbilical angle in both sutures and sections. In the sutures, the first denticulation is shown on the external saddle, new frillings coming in rapidly from that time onwards. Although the relative proportions of these divisions are not the same in the sections as in the sutures, the numbers at the various stages are practically identical. The difference in proportions may be partly explained by the difference between Mr. Spath's specimen and ours, as mentioned previously. It may also be suggested that the notches which produce 'undercuts' on the folds are confined to the edge of the septum, and are therefore necessarily shown only in the sutures, yet are absent from the inner portions of the early as well as the latest septa. This last fact is of practical value in breaking up an ammonite for examination: for, if the outer surface is filed a way along any suture-line, the chambers may be readily separated.

\section{Septal Sections of Spharoceras brovg.viarti (J. Sowerby). (See figs. $15 \& 16$, p. 48.)}

The septal sections of this specimen correspond very closely with the developmental series. The order of appearance of denticulations in ontogeny is closely paralleled in the sections. Thus the first frillings in each series are developed in similar positions on the external saddles (compare fig. $16 c \& d$ with fig. $15 c$ ) after the appearance of the median saddle in the ventral lobe. At this stage there are three pairs of saddles in both cases. The development of additional frillings and of small auxiliaries also proceeds along almost identical lines. It will be noted, however, that in ontogeny the median ventral saddle is present at an earlier stage than in the sections : namely, before the development of the second lateral saddle. The differences noted in the previous comparisons are also to be seen here; the undercuts, which are well developed in ontogeny, are only preserved in the outer parts of the septum, and consequently do not appear in any but the outermost sections. Further, even in the inner septal sections, main folds are generally more acute than in development. This is due to the absence of a - central flattened area. 


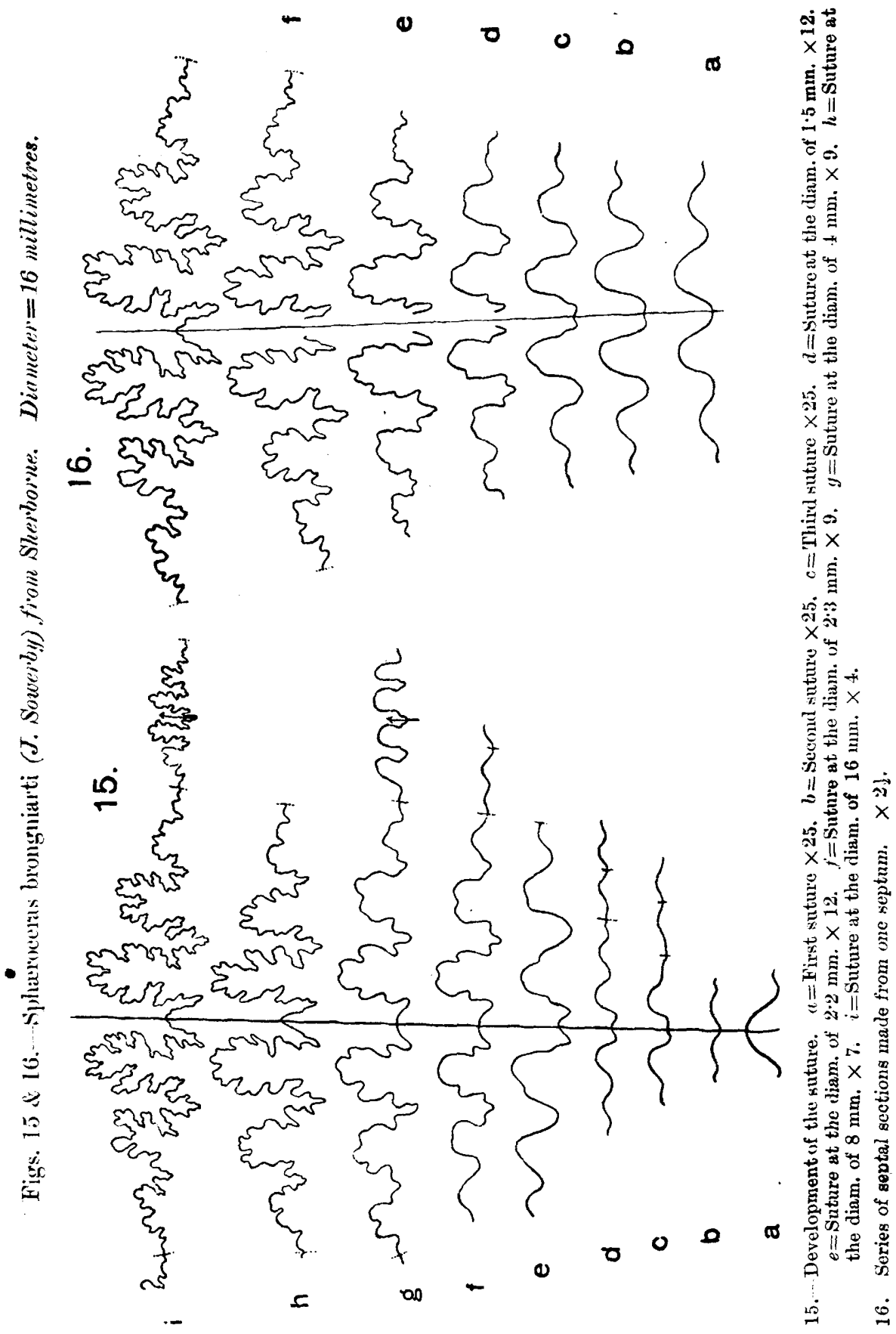


part 1] THE MORPHOLOGY OF THE AMMONITE SEPTUM.

Nevertheless, the similarity is sufficiently striking to justify the opinion that the principle eluced from the septa of normally-shaped and compressed whorls holds good also, with the limitations noticed, for forms with depressed whorls.

Fig. 17.-Section of the whorl of Spharoceras brongniarti along the datum-plane of the septum of which septal sections are shown in fig. 16 (p. 48). The lines parallel to the periphery show the positions of these sections.

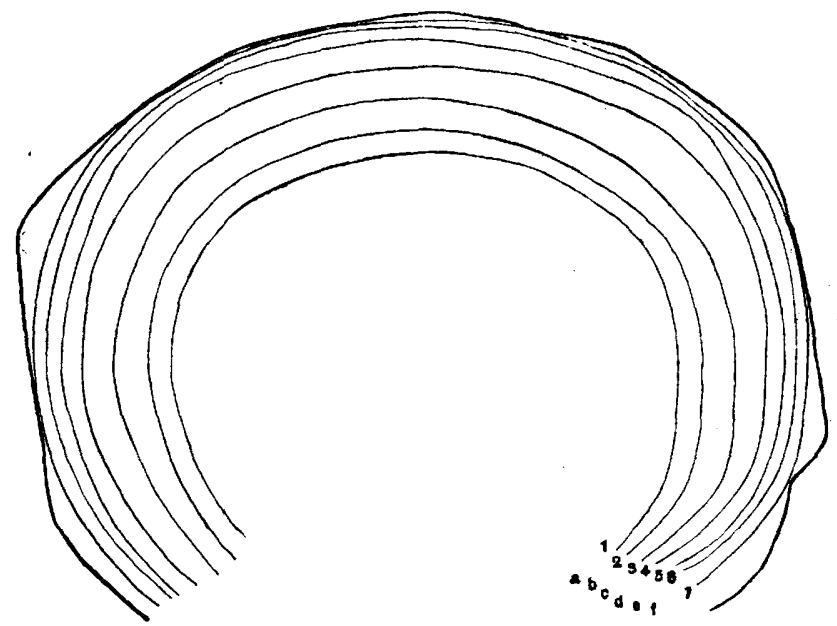

\section{The Geveral Constperation of Septal Sections.}

Mr. R. 'T. Jackson 1 has drawn attention to the phenomenon of localized stages in development: that is to say, during life ' stages may be found in localized parts which are similar to stages found in the young, and the equivalents of which are to be sought in adults of ancestral groups.'

Thus, for example, the auxiliary saddles in the suture of Tragophylloceras are similar to the external and lateral saddles of the first suture. 'The idea has been applied to the study of different species in a progressive series (Lytoceress) by Mr. S. S. Buckman,? who has shown that the first lateral saddle of an early type is at the same stage as the second lateral of a more advanced type.

The similarity of the central area of the adult septum to the earlier septa is not, however, an illustmation of the same principle. All Jackson's illustrations are drawn from newly developed parts,

1 'Localized Stages in Development in Plants \& Animals' Mem. Boston Soc. Nat. Hist. vol, v (1899) p. 92.

2 'On certain Genera \& Species of Lytoceratidæ' Q. J. G. S. vol. lxi (1905) p. 151.

Q. J.G.S. No. 289. 
such as the auxiliaries of suture-lines, the last-formed plates in the stalk of a crinoid, or in the interambulacral area of an echinoid. The simplicity of the central area of the adult septum is due to the retention of this feature throngh all stages of development, despite the increasing complexity of adjoining parts.

Just as the development summarizes the stages of evolution with omissions here and additions there, so septal sections summarize the development, but with omissions only. 'The features to be omitted are determined by the fact that the series of changes, shown in the passage from the centre of the septum to the edge, represents the most direct way in which the adult septum, with its highly complicated margin, could have been evolved from a septum as simple as that of an asellate protoconch. If this course of evolution has been, as it were, a winding one, the winds will be omitted, to sone extent in development, and completely in the adult septal sections.

In ammonites with normally-shaped whorls the septal sections closely resemble the sutural development: in highly-compressed and depressed forms, however, the central area of the septum is like a primitive septum greatly elevated or laterally extended. During ontogeny, the first lateral saddles in these forms early assume adult proportions, and consequently in septal sections the stages represented by the earliest sutures are omitted. In no case do septal sections show a stage comparable with the first suture. This seems to indicate that, in ammonites, a change akin to a metamorphosis took place in the period between the formation of the first and the second septum. 'The creature which secrete: the former was possibly larval, and followed a line of evolution of its own : which is reflected in the series of ccenogenetic changes represented by the terms a sellate, latisellate, and angustisellate. Further, in such forms as Pinacoceras, where a large number of adventitious inflections are developed, and compression has reached its maximum, we should not expect to find so close an agreement between the septal sections and the sutural development.

With these exceptions, however, septal sections will at least furnish a standard of direct development, ${ }^{1}$ which may be useful for detecting deviations in the normal development where such occur. This direct development may or may not approach as closely as ontogeny to a true reprisentation of actual evolution.

Septal sections should prove especially useful where material for the study of early stages is not accessible. Although, in ordinary cases, sutural development may prove of greater value than the septal sections, where the former cannot be worked out the latter will, to some extent, serve as a substitute.

It is well known that the sutures of senile stocks bear a close resemblance to the young sutures of the advancing types which preceded them. This resemblance is due, not to a resumption of

1 We owe this suggestion to a conversation with that brilliant and much lamented investigator, the late Dr. A. Vaughan. 
part 1] ON THE MORPHOLOGY OF THE AMMONITE SEPTUM.

embryonic characters which have disappeared as the study of the suture-lines alone seems to suggest, but to a bringing to the surface once more of those embryonic features which, even in acmic radicals, have persisted into adult life hidden from view by a narrow fringe of complicated frilling. During retrogression this fringe is gradually lost, and thus a process analogous to the making of septal sections takes place. Strictly, the sutures of senile stocks shouid be compared, not with those seen in the ontogeny of ancestral types, but with the septal sections of the ancestral adult septum. It is not at all unlikely that, while ontogeny summarizes progressive evolution, septal sections forecast in similar broad outlines retrogressive evolution. Thus, for example, a careful study of a large number of Baculites, and a comparison with the septal sections of ammonites from which they have probably descended, would make it possible to connect up with certainty many of these forms. It is to be regretted that inability to secure sufficient material has made it impossible for us to establish this principle satisfactorily.

\section{Asymatetry in Suture-Lrines.}

A marked tendency to asymmetry in suture-lines has already been noted in Dactylioceras commune. It is now proposed to deal with this aspect of the morphology of the septum more fully. Such asymmetry usually arises in one of two ways, namely :-

(1) By the different development of elements of opposite sides.

(2) By association with lateral displacement of the siphuncle.

The former is of common occurrence. It has already been described above for Dactylioceras (p. 40). It has been observed by S. S. Buckman in Sonninia ${ }^{1}$ and by Solger in Neoptychites. ${ }^{2}$ In each of these cases the first lateral lobes of opposite sides were different in plan. Other cases have been seen in which this character has been associated with a tendency to helicoid coiling, as in the 'Turrilites' of d'Orbigny. ${ }^{3}$ As O. Fraas has shown, ${ }^{4}$ it is only when this character has become constant, as in Turrilites, that it is of generic importance.

Asymmetry associated with the displacement of the siphuncle may be brought about in various ways. The most instructive example that has come under our notice is that of a specimen of Perisphinctes triplicatus, found in the Kimeridge Clay of Market Rasen by Mr. F. T. Ingham. This specimen shows three septa (Pl. IV, fig. 2); the suture of the earliest is normal, that of the second is slightly irregular, that of the third is markedly distorted, for the siphuncle has during this short interval become

1 'Inf. Ool. Ammonites' Monogr. Prlæont. Soc. 1894, p. 381.

2 'Die Fossilien der Mungokreide in Kamerun \& ihre Geologische Bedeutung' Beitr. Geol. von Kamerun (1904) p. 107.

3 'Paléontologie Française : Terrains Crétacés' vol. i (1840) p. 571.

4 'Abnormitäten bei Ammoniten' Jahreshefte Württemb. xix (1863) p. 112. 
considerably displaced from the median line. These features of the suture-line are only an external manifestation of an enlargement of one half of the septum (fig. 1) at the expense of the other; in such a manner that the internal as well as the external lobe has been pushed to one side, and the enlarged half has also been pushed behind the general level of the septum. That the asymmetry is not due to an injury seems probable, since it developed slowly enough to permit of the secretion of at least two septa. Neither does it appear to have been due to a change of the conditions which directly affect the form of the suture, since all the details are preserved. The cause was possibly pathological. The facts already discussed show that the form of the septum, even in these asvmmetric examples, is independent of the internal organs in the neighbourhood of the septum: otherwise a diseased condition of some paired organs (for instance, the gonad) might have been postulated. As it is, the cause must be looked for in a diseased condition of the stretched membrane: namely, the septum-secreting area of the mantle. If this became hypertrophied on one side, it would still assume the form of a stretched membrane, but being more resistant to pressure from behind, would not become so concave forwards as the other half. 'This is precisely the condition which the shape of the abnormal septum suggests.

Usually the change in the position of the siphuncle takes place slowly and in one direction only; but in a specimen of Hoplites auvitus (Pl. IV, fig. 8) it moves from side to side repeatedly, in association with the alternate development of tubercles on opposite sides of the venter. 'The mantle apparently sank into the cavities of the tubercles, and thus caused a displacement of the adjoining parts of the body as well as of the mantle.

Lateral displacement of the siphuncle in the example of Perisphinctes which we have just described has been accompanied by wholesale enlargement of one half of the septum, but usually only the rentral features of the suture are affected. Thus in the septun of Hoplites splendens (Pl. IV, fig. 4) all the elements of the internal series and those of the external series which are dorsal to the first lateral lobe, are quite normal. Further, in the septum of Psiloceras planorbis (Pl. IV, fig. 9), the displacement is of a character similar to that observed in Hoplites splendens : for there also the dorsal suture is not affected, while the elements of the venter are disturbed even more markedly than in the latter form.

Thus the displacement of the siphuncle in Perisphinctes and Hoplites auritus is different in origin from that of Psiloceras and Hoplites splendens. Dr. J. F. Pompeck ${ }^{1}$ has, for example, stated that the type of asymmetry in Psiloceras is of systematic value. 'The discovery, also by him, of a specimen of Tragophylloceras with a similarly asymmetric suture-line, has been mentioned

1' 'Beitrüge zu einer Revision der Ammoniten des Śchwäbischen Jura' pt. i (1894) pp. 56-71. 
by Spath (op. cit. 1914, p. 351), presumably as corroborative evidence of the commexions between Psiloceras and Tragophylloceras. ${ }^{\text {I }}$ Similarly, this character has been described in Cosmoceras by Teisseyre. ${ }^{2}$ Sayn ${ }^{3}$ mentioned that he had not observed a similar feature in Hoplites, and considered that this showed conclusively that Hoplites was not directly descended from Cosmoceras. It should be mentioned, however, that A. d'Orbigny (1840, p. 222) had previously noticed that asymmetry is of common occurrence in certain species of Hoplites-an observation which we are able to confirm.

An examination of sixteen specimens of Psiloceras planorbis from the Lower Lias of Robin Hood's Bay revealed asymmetry in nine cases. Although asymmetry is of common occurrence in Psilocercs, it would appear to be an unreliable character. Further, Pompeck's figures show that the displacement varies in amount and direction.

The careful examination of the suture-lines of more than 600 Jurassic and Cretaceous ammonites has shown that asymmetry due to a displacement of the siphuncle occurs sporadically in many widely-separated genera. We have noticed it in the following cases:-

Psiloceras planorbis (Sowerby). ${ }^{4}$ N.U.C., N.M. Robin Hood's Bay. 9 out of $16 . \quad$ Pl. IV, fig. 9.

'Normannites' braikenridgi (Sowerby). N.M. Mesvil (Yorkshire). 1 out of 2. Pl. IV, fig. 13.

Keplerites calloviensis (d'Orbigny). N.U.C., N.M. Ashton Keynes. 1 out of 3.

Aspidoceras perarmatum (Sowerby). N.U.C., N.M. Faringdon. 2 out of 4.

Hoplites splendens (d’Orbigny). N.U.C., N.M., B. Folkestone; Cambridge. 62 out of 112.

Hoplites raulinianus (d'Orbigny). N.M. Folkestone. 1 out of 2.

Dactylioceras commune (Sowerby). N.U.C., N.M., B. Whitby, etc. 10 out of 30 .

Cosmoceras jason (Reinecke). N.U.C., N.M. Woburn Sands. 5 out of 12.

The occurrence of asymmetry in so large a number of examples of Hoplites is noteworthy, and fully bears out d'Orbigny's observation. Yet it should be mentioned here that, in 78 specimens of Hoplites lautus and H. tuberculatus, we were unable to detect

1 Mr. Spath remarked that he had not observed any cases of asymmetry in the specimens of Tragophylloceras loscombi from Lyme Regis. Mr. W. D. Varney, however, has found an example of this species showing asymmetry at Old Dalby (North Leicestershire).

2 ' Ein Beitrag zur Kenntniss der Cephalopoden Fauna der Ornatenthone im Gouvernement Rjäsan (Russland)' Sitz. Math.-Naturw. Classe, K. Akad. Wissensch. Wien, vol. lexxviii, pt. 1 (1883) pp. 538-69.

3 'Ammonites Pyriteuses des Marnes Valangiennes du S.E. de la France' Mém. Soc. Géol. France, Paléont. vol. xv (1907) p. 65.

+ N.U.C. $=$ Teaching Collection, University College, Nottingham ; N.M. $=$ Natural History Museum, Nottingham ; B. = Teaching Collection, Birmingham University. 
one case of asymmetry, Further, asymmetry of a similar character has been observed by previous writers in a large number of other forms :-

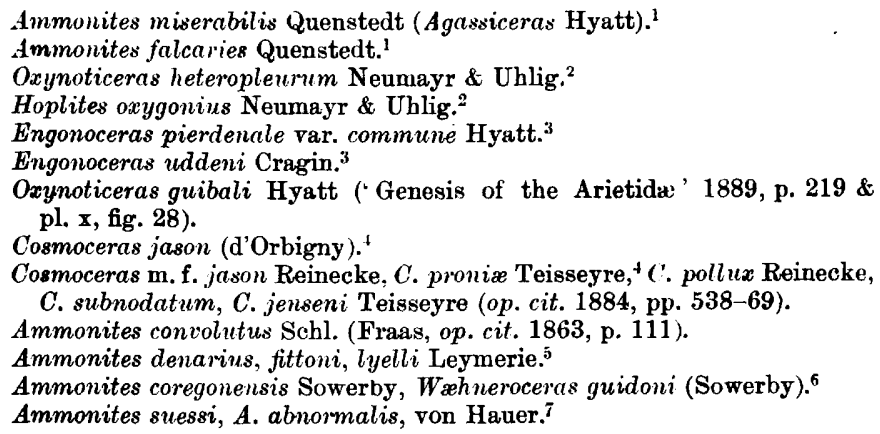

It will be noted that the greater number of the fossils in which this type of asymmetry has been observed are included in, or connected with, the families Cosmoceratidæ, Fgoceratidæ, and Stephanoceratidæ (according to the classification adopted by J. P. Smith) ${ }^{8}$ Thus it would at first appear that the feature is of considerable systematic importance; yet it should be remembered that, although asymmetry is typical of certain species of Hoplites, in other species of the same genus we have not observed it. The presence or absence of examples of asymmetry, therefore, must not be taken as conclusive evidence of relationship in the face of other facts.

An examination of the lists just given shows that nearly every specimen in which this type of asymmetry has been observed has a rounded or flat venter. Although at least a third of the specimens examined had keeled venters, not one case of asymmetry has been detected by us among them. It would thus appear that the displacement is to a large extent associated with the shape of the whorl. Nevertheless, asymmetry may occur occasionally in

' F. A. Quenstedt, 'Die Ammoniten des Schwäbischen Jura' Stuttgart, 1885, pl. xiii, figs. 15, 29.

${ }^{2}$ M. Neumayr \& V. Uhlig ' Ueber Ammoniten aus den Hilsbildungen Norddeutschlands.' Palæontographica, vol. xxvii (1880-81) pp. 135, 171.

${ }^{3}$ A. Hyatt, 'Pseudoceratites of the Cretaceous' U.S. Geol. Snrv. Monogr. xliv (1903) pp. 159, 165.

4 A. d'Orbigny, 'Paléontologie Française: Terrains Oolitiques ou Jurassiques' vol. i (1842) p. 448. 55.

M. Neumayr \& V. Uhlig, Palæontographica, vol, xxvii (1880-81) pp. 219-

6 P. Savi \& G. Meneghini, 'Osservazioni stratigrafiche \& paleontologiche concernenți la Geologia della Toscana' 1851, pp. 73-77.

7 F. R. von Hauer, 'Ueber einige unsymmetrische Ammoniten aus den Hierlatzschichten' Sitz. Math.-Naturw. Classe, K. Akad. Wissensch. Wien, vol. xiii (1854) pp. 401-410.

'Cephalopoda, in K. von Zittel's 'T'ext-book of Palæuntology' (transl. Eastman), 2nd ed. (1913) p. 150. 
some keeled forms; for it has been recorded in Ammonites miserabilis Quenstedt, in Orynoticerms heteroplewrum, and in O. guibali. In the latter genus, at all events, the exception is only apparent, for the venter may be strictly considered as rounded, on account of the hollow keel. ${ }^{1}$

Asymmetry has been observed in Hojplites tubreculatus by G. C. Crick, ${ }^{2}$ but here it was accompanied by a distortion of the shell; yet a specimen with asvmmetric ornament may have a normal suture, as seen in an example of Ammonites amaltheus. ${ }^{3}$

The asymmetry which occurs so commonly in Hoplites splendens and $H$. raulinianus is usually accompanied by the displacement of the siphuncle into the angle bounding the flat venter. At $12 \mathrm{~mm}$. diameter in each of the specimens the sutures were symmetrical, and at this stage the specimens had round venters. (Pl. IV, fig. 5 a). From this stage until a whorl later (Pl. IV, tig. $5 b$ ) the siphuncle became gradually more displaced; but only the ventral part of the septum became distorted, for all the features dorsal to the first lateral lobe remained normal. Similar characters were observed by $\mathbf{A}$. d'Orbigny ${ }^{4}$ in the development of asymmetry in Ammonites denarius. Asymmetry in these cases is probably a growth phenomenon, associated with the tendency of the siphuncle to take up a stable position along the angle bounding the venter.

Accompanying the displacement there has been in many forms a rapid change in the form of the suture, which is probably a result of the increased area on that side of the siphuncle. It illustrates the manner in which the form of a suture may be changed owing to a rapidly increased height of whorl. Thus in Hoplites splendens ( $\mathrm{Pl}$. IV, figs. 4-6) the external saddle at first has two main divisions; but later it becomes trilobed. Further, in Cosmoceras ( $\mathrm{Pl}$. IV, fig. 10) the external saddle of the enlarged side is practically double the breadth of the corresponding saddle of the other side. In association with this increase in relative size the saddle has become more deeply denticulated, and the major frillings have become indented by numerous minor frills which are but feebly represented on the other side. 'This peculiarity has been studied in some detail by Teisseyre.;

He suggested that the displacement that we have described is a growth-phenomenon associated with the form of the whorl. Solger ${ }^{6}$ believed that the movement of the siphuncle away from the median plane was due to the adoption of a recumbent habit.

1 A. Hyatt, Smithsonian Contributions to Knowledge, No. 673 (1889) pl. x, fig. 28.

2 'A deformed example of Hoplites tuberculatum,' Geol. Mag. dec. 4, vol. v (1898) p. 541.

3 o. Fraas, Jahreshefte Württemberg, xix, 1863, p. 111.

4 A. d'Orbigny, 'Palcontologie Francaise: Terrains Crítacís' vol. i (1840) p. 222.

5 L. Teisseyre, Sitz. Math.-Naturw. Classe, K. Akad. Wissensch. Wien, vol. Ixxxviii, pt. 1 (1883) pp. 604-608.

c F. Solger, 'Beiträge zur Geologie von Kamerun,' 1904. 
Dr. O. Abel ${ }^{1}$ considers that, while many ammonites were adapted for a swimming life, yet many of the 'one-sided' forms that we. have mentioned had a benthic habit. He also suggested that the presence of a keel in a nectonic animal would assist rapid motion. As we have seen, asymmetric siphuncles rarely occur among these keeled forms, which presumably had rarely a benthic habit.

Briefly then, although a displaced siphuncle and an asymmetric suture may be most usually developed in certain connected species, the existence of such abr normalities in a single specimen is not sound evidence of genetic affinity.

In conclusion, we wish to express our thanks to those who have helped us : to W. I. Lang, M.A., F.G.S., for gifts of material; to Prof. J. W. Carr, M.A., F.G.S., for permission to examine the collection in the Nottingham Museum; and to Prof. W. S. Boulton, F.G.S., for allowing us similar access to the collection in the Birmingham University.

\section{EXPLANATION OF PLATES II-IV. \\ Plate II.}

Fig. 1. Apparatus used in surveying and lerelling the surfaces of septa and of whorls.

2. Dactylioceras commune (J. Sowerby), from Whitby. Specimen used for working out the development of the septum, the suture-line, and for making septal sections. Diameter $=7.5 \mathrm{~cm} . \quad \times \frac{2}{3}$.

3. Portion of the whorl of another specimen of the same species filed away in steps, in order to show septal sections of successive septa. $\times 1 \frac{1}{2}$.

4. Series of septal sections drawn from this specimen.

\section{Plate III.}

Figs. 1-5. Development of the septum of Dartylioceras rommune. Figs. 2-5 are from the specimen shown in PI. II, fig. 2.

Fig. 1. Adult septum. $\times 4 \cdot 5 . \quad$ (Text-fig. 4.$)$

2 . Septum at $2 \frac{3}{4}$ whorls. $\times 22$.

3. Do. at $2 \frac{3}{4}$ whorls. $\times 25$.

4. Do. at $1 \frac{3}{4}$ whorls. $\times 35$. The numbering of figs. 4

5. Second septum. $\times 40$. (Text-fig. 6. p. 36.) $\} \& 5$ should be reversed.

6. Almost adult septum of Tragophylloceras losrombi (J. Sowerby), from Lyme Regis. Diameter $=17 \mathrm{~mm} . \quad \times 6$.

7. Adult septum of Spheroceras brougniturti (J. Sowerby). from Sherborne. Diameter $=20 \mathrm{~mm} . \times 2 \frac{1}{2}$.

\section{Plate IV.}

Figs. 1-3. Perisphinctes tripliratus, from Market Rasen.

Fig. 1. Front riew of an ahnormal septum. Natural size.

2. Ventral view of a portion of an outer whorl. Natural size.

3. Last suture shown by this specimen.

1 'Verbreitung \& Lebensweixe der Ammoniten' Verhandl. k.-k. Zool.-Botan. Gesellsch. Wien, 1912, p. 83. 
part 1] ON THE MORPHOLOGI OF THE AMMONITE SEPTUM.

Figs. 4-6. Hoplites splendens. Diameter $=34 \mathrm{~mm}$.

Fig. 4. Septum showing displaced siphuncle, and distortion associated therewith.

5 a. Suture of the same at $12 \mathrm{~mm}$.

5 b. Do. do. at $32 \mathrm{~mm}$.

6. Do. of another specimen.

7. Hoplites raulinianus. Folkestone. Suture.

8. Hoplites auritus. Cambridge. View of venter showing displacement of the siphuncle, first to one side and then to the other.

9. Psiloceras planorbis. Robin Hood's Bay. Showing position of displaced siphuncle.

Figs. 10-15. Asymmetrical sutures of various ammonites.

Fig. 10. Cosmoceras jason. Buckinghamshire.

11. 'Normannites' braikenridgii. Mesvil.

12. Aspidoceras perarmatum. Faringdon.

13. Uptonia jamesoni.

14. Keplerites calloviensis. Ashton Keynes.

15. Dactylioceras commune. Whitby.

IL $=$ Internal lobe. $\quad E S=$ External saddle. $\mathrm{L}^{1}=$ Principal or first lateral lobe. $\mathbf{L}^{2}=$ Auxiliary lobe. $\quad \mathbf{S}^{\mathbf{1}}=$ First lateral saddle. $\mathbf{M}=$ Median plane. Sip. $=$ Siphuncle.

\section{Discussion.}

Dr. F. A. Butrer thanked Prof. Swmnerton for his wellillustrated and lucid exposition. It had been said that in science the invention of a new method was worth more than the discovery of a hundred facts. The instrument devised by the Authors might be applied to the reproduction of other complicated surfaces. 'The ammonites illustrated had all been progressive types, and apparently the method was unsuitable when retrogression had set in. In progressive types the study of a late-formed septum enabled one to work backwards, but not forwards, to the unknown. Might it not, however, be possible to forecast the lines of retrogression? In any case, the method would facilitate the determination of affinities and the plotting-out of definite series on which more secure inferences could be based.

Dr. A. M. DAvies said that the suggestion that septal sections might be used as a means of studying the development of the septum had been made to him in conversation by Mr. S. S. Buckman some years ago. He congratulated the Authors on their success in demonstrating the truth of this suggestion. He enquired as to how far coarse ornamentation would interfere with the application of the method, and whether it was really trustworthy in the case of septa which had undergone catagenetic simplification.

Prof. H. H. Swinnerton thanked those present for the kind reception given to the paper. Replying to Dr. Bather, he stated that 'septal sections' supplied a standard of the most direct line of development leading up to the condition found in the particular septum from which they had been made; for that reason they would not record any deviations from that line occurring during evolution or development. The study of the septal sections of a simple

Q. J. G. S. No. 289. 
58 THE MORPHOLOGY OF THE AMMONITE SEPT M. [Vol. IrXiii.

septum could not be expected to throw light upon the possible complications which might arise in the future in a progressive series. On the other hand, sections of a coinplicated septum such as that of Lytoceras might reasonably be expected to show resemblances to the sutures of any species of Baculites of Lytoceratan arigin. Replying to Dr. Davies, he expressed the opinion that the presence of coarse ornamentation on the surface of an ammonite would not seriously impair the usefulness of septal sections. The resemblance of the inner part of the septum to the early septa was not really an example of the phenomenon defined in the phrase 'localized stages in development.' 


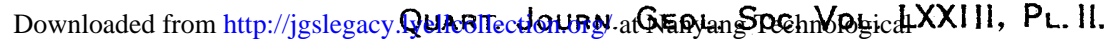
University on May 9, 2016

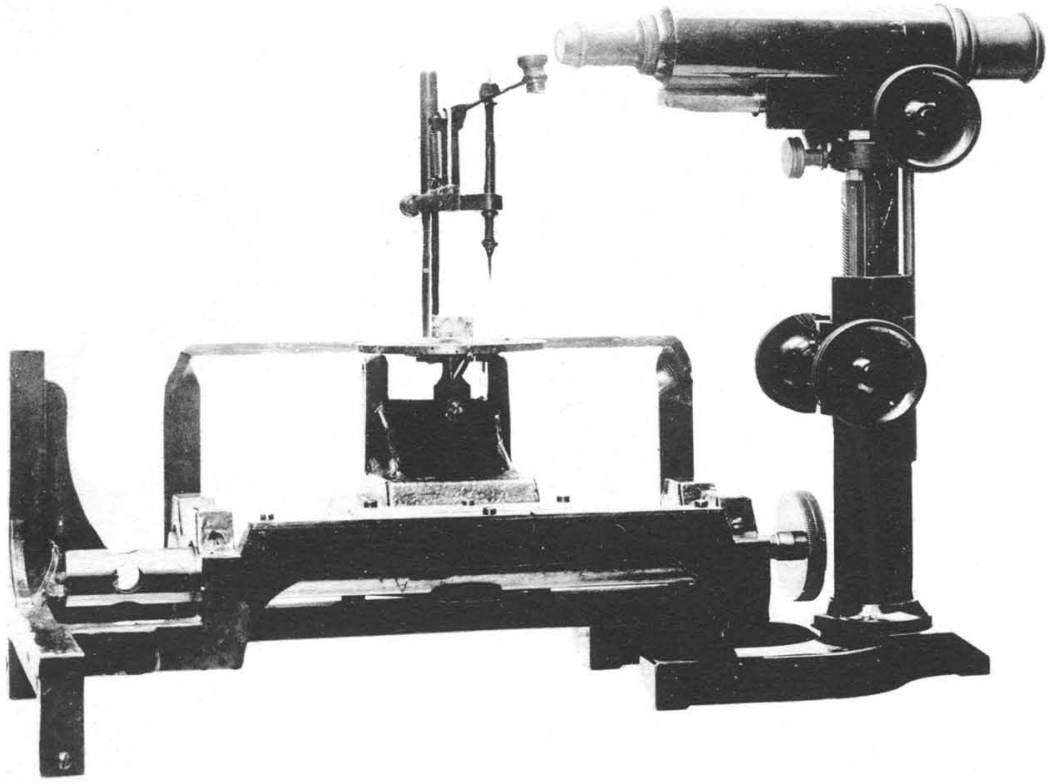

4.

2.
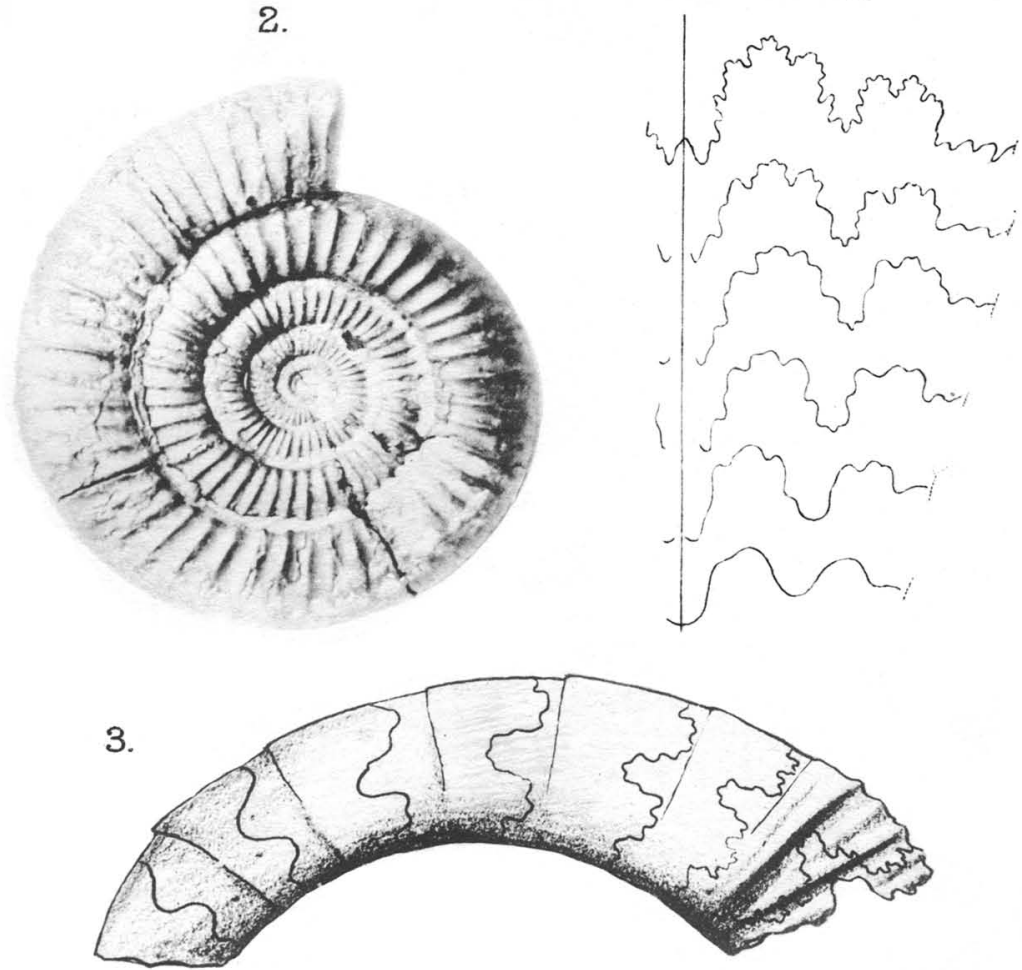

A.E.T., del.

Bernros?, Collo,, Derby DEVELOPMENT OF THE AMMONITE SEPTUM. 


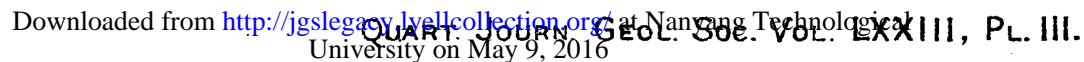

1.

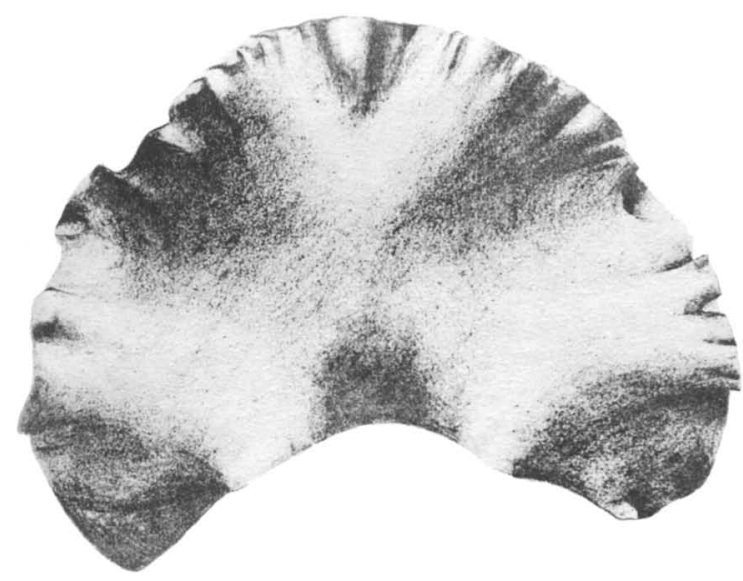

2.

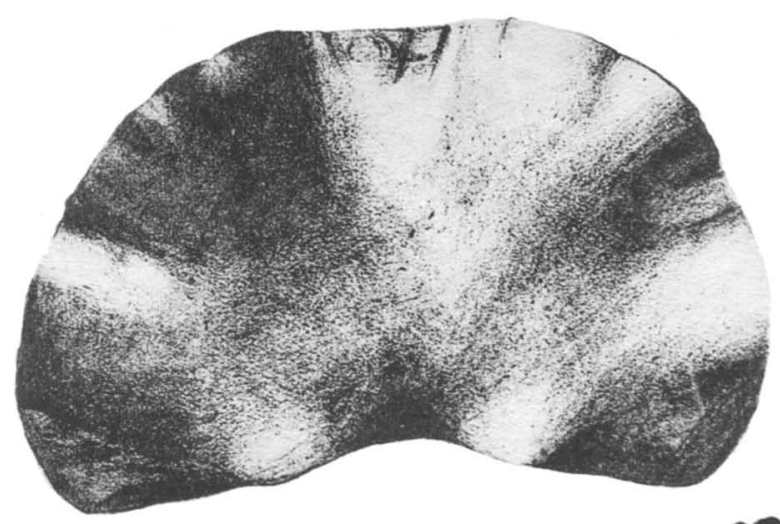

3.
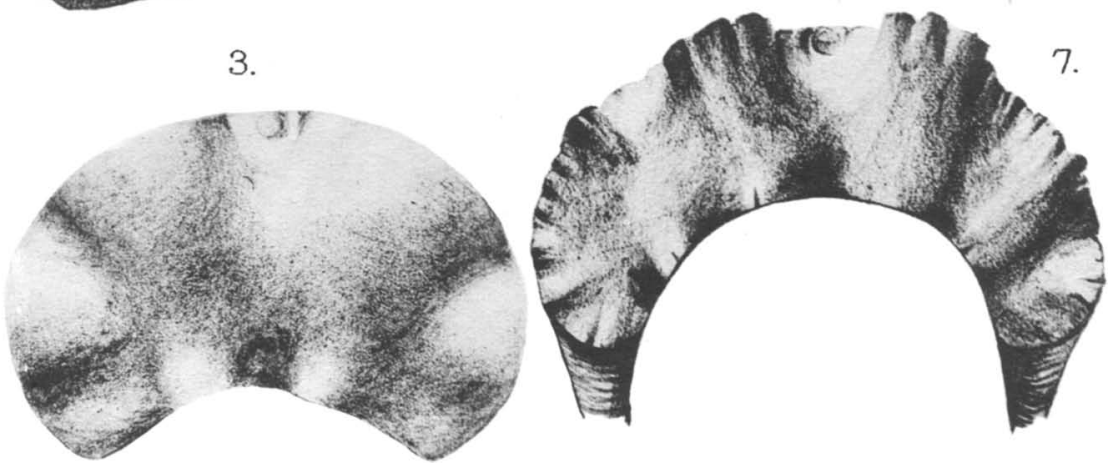

4.

5.

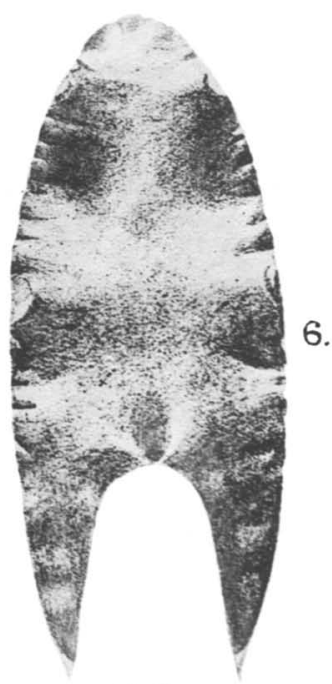

6.

7.

Bemrose, Collo, Derby

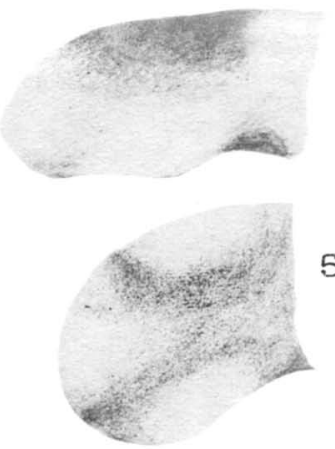

A.E.T., del. 


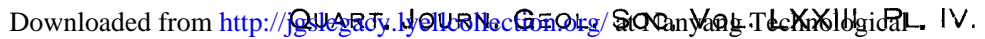
University on May 9, 2016

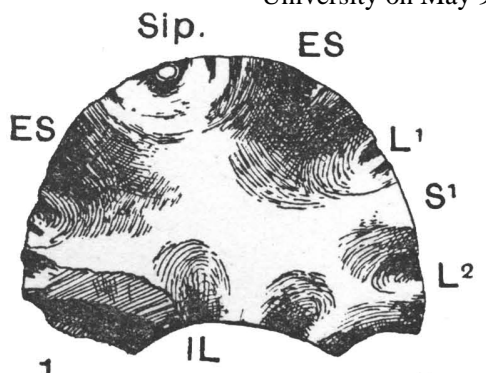

1.

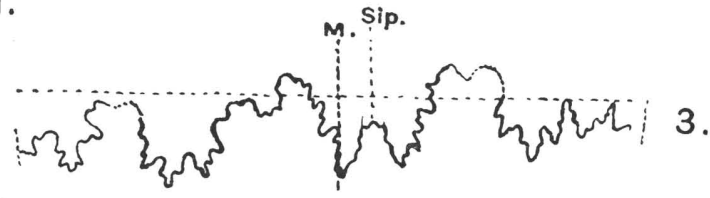
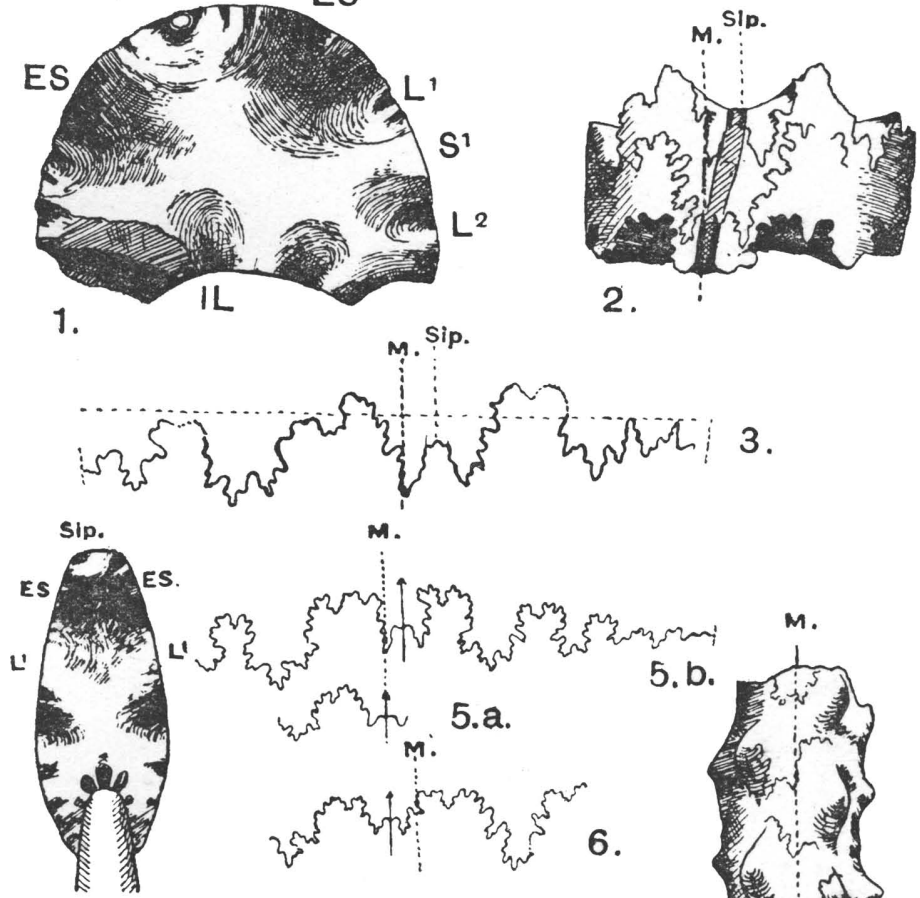

4.

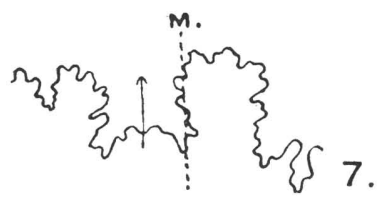

5.b. 5. 2क्ष

6. Sip.

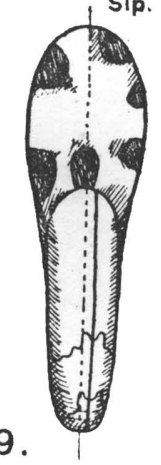

10. ई $^{5}$ हn

11. 约

13.

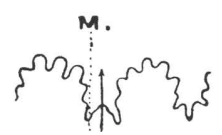

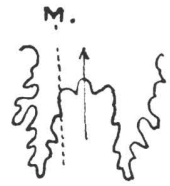

14.

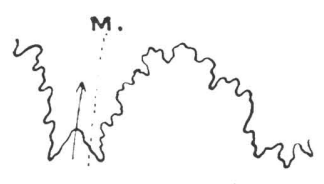

15.

A.E.T., Del. 